Journal of Economic,

Administrative and Legal Sciences

Volume (6), Issue (2): 30 Jan 2022

P: 1 - 28

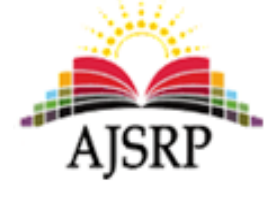

ISSN: 2522-3372
مجلة العلوم الاقتصيادية

والإدارية والقانونية

المجلد (6)، العدد (2): 30 يناير 2022 م

ص: 1 - 28

\title{
The reality of Taibah University and the opinions of its leaders and affiliates on the obstacles and possible alternatives to increase and diversify the university's funding in the American and British experiences
}

\author{
Abdulaziz Yehia ALamri
}

Taibah university $\|$ KSA

\begin{abstract}
This study aimed to investigate the status of alternative funding in Saudi Arabia using Taibah University as a model. specifically, the study tried to discover obstacles to alternative funding at Taibah University to suggest mechanisms to improve it in light of the experiences of advanced countries. to achieve the objectives of the study, the research used mix approach design using questionnaire and interview tools to collect data. The researcher sampled 140 participants consisting of deans, vice-deans, Faculty members, and employees of Taibah university. The items of the questionnaire and following up interview were developed by the researcher and validated by experts in the field. The SPSS version 25 was used to analyze the collected data to compute descriptive and inferential statistics. The results of the study showed that the major sources of funding for Taibah comes from the government (About 99\%) while self-Generated resources represent early a small percentage (around 1\%). The self-generated Resources come from three sectors: Tuition fees, investment, and Endowment. The result also showed the overall participants' agreement on the obstacles to finding a Taibah in University is 3.95 out of 5. The major obstacles found are administrative bureaucracy (4.36) and the lack of the private scoter involvement in in the field of education (4.18), among others. as for the use of experiences in developed countries as mean to alternative funding, there is a high (4.12 out of 5) agreement among participants. The most agreed are the use of costsharing (4.53), and endowment (4.53). in light of these findings, the researcher made four recommendations for improvement and future studies. The first one is to Reduce the Administrative bureaucracy to facilitate self-fund generation and encouraging the private sector to invest in education. The second one is to focus more on investment strategies to make the university resources and donations more efficient. The third one is to make use of alternative schemes of funding from developed countries that can be adapted in the context of Saudi Arabia. The last one is to conduct further studies on the topic to help validate these findings and gain additional information based on which means to reduce reliance on government funding can be educed.
\end{abstract}

Keywords: Alternative Funding, Higher Education, Obstacles, Taibah University.

$$
\begin{aligned}
& \text { و اقع التمويل بجامعه طيبة وآراء قياداتها ومنتسبيها بالمعوقات والبدائل الممكنة } \\
& \text { لزيادة موارد الجامعة وتنويحها في ضوء التجارب الأمريكية والبريطانية واليابانية } \\
& \text { عبد العزيزيحيى العامري } \\
& \text { جامعة طيبة || المملكة العربية السعودية }
\end{aligned}
$$


المستخلص: هدفت الدراسة إلى تشخيص واقع بدائل التمويل في جامعة طيبة، والكشف عن معوقات بدائل التمويل فهيها، وتحديد مقترحات

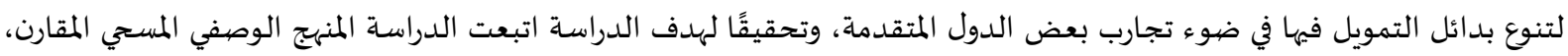

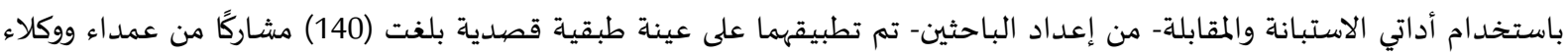

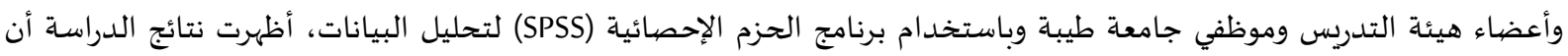

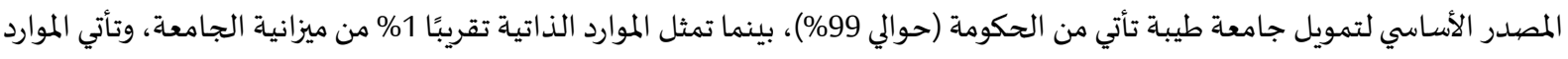

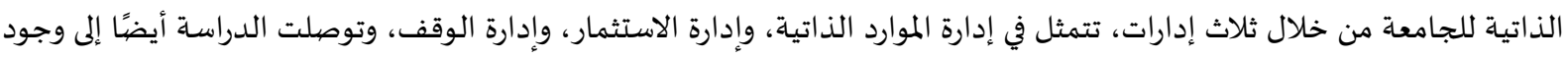

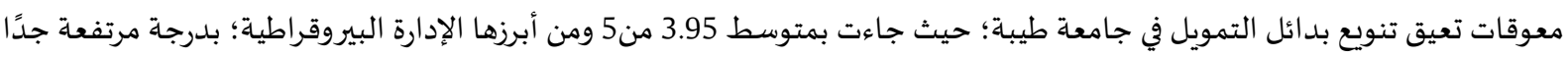

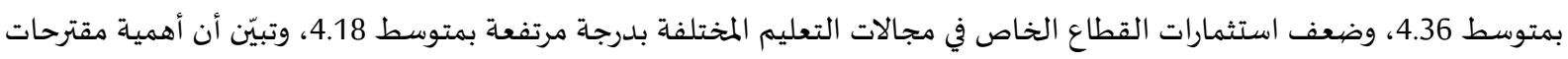

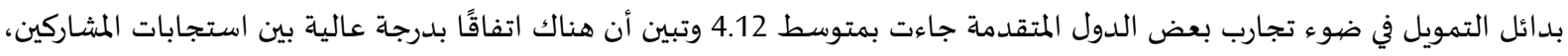

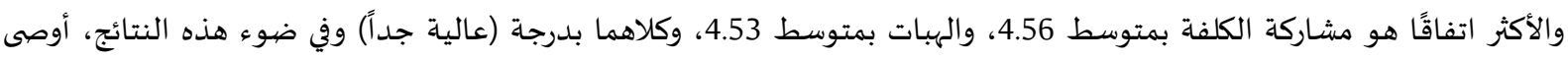

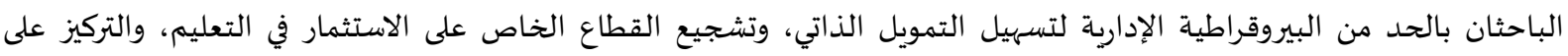
استراتيجيات الاستثمار لجعل موارد الجامعة والتبرعات أكثر كفاءة.

الكلمات المفتاحية: بدائل التمويل- المعوقات - التعليم العالي - جامعة طيبة.

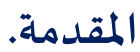

يشهد العالم في هذا العصر تغيرات سريعة وبارزة على جميع الأصعدة، ومنها اقتصاد التعليم الذي يشجع على ولى

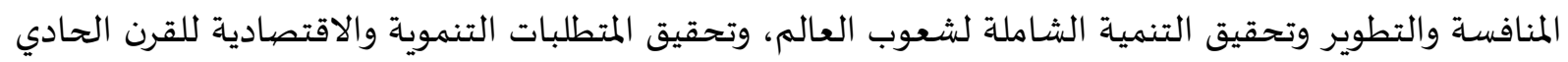

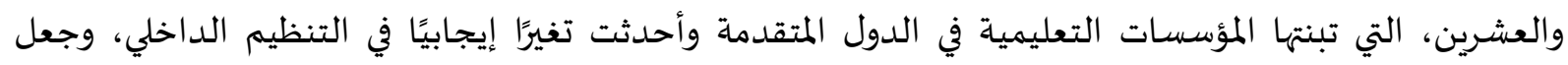
الجامعات كوحدة إنتاجية تعتمد على ذاتية التمويل الداخلي.

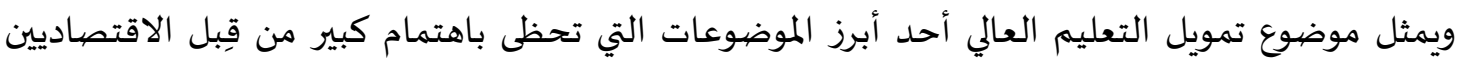

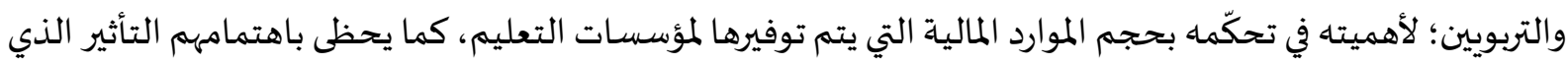

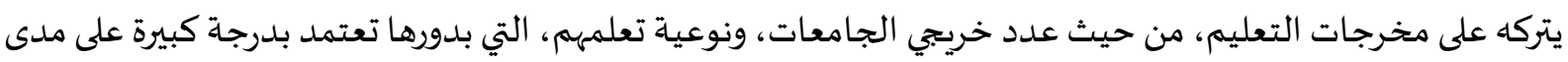

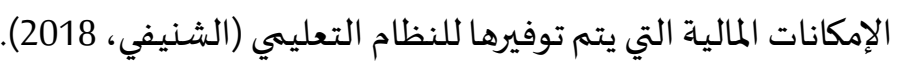

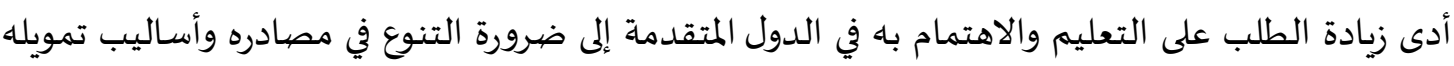

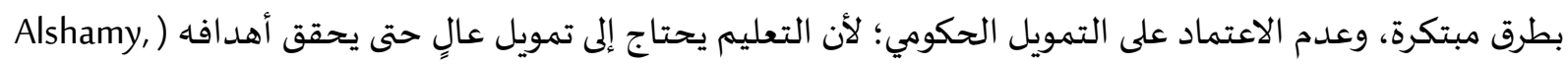

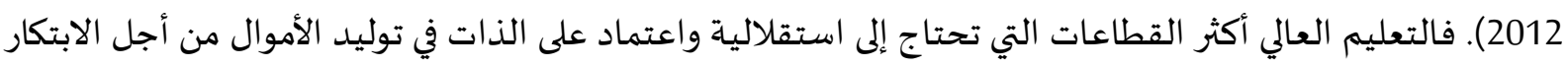

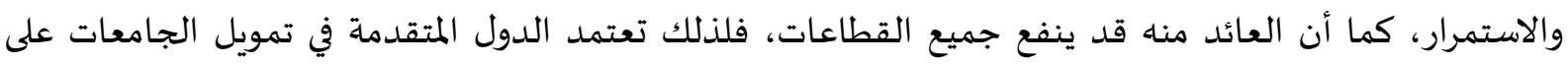

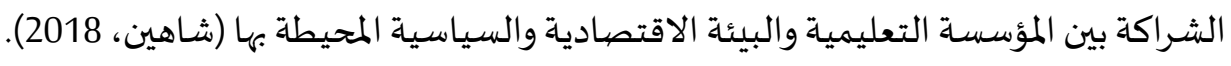

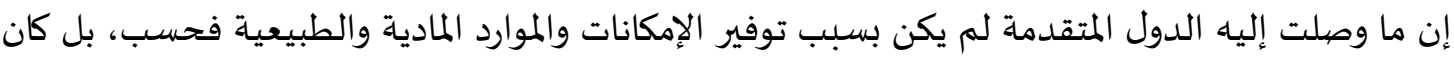
بإشراك الجامعات في تحقيق أهداف الخطط التنموية، إذ كان على الجامعات إيجاد البدائل اللازمة لعملية التنمية،

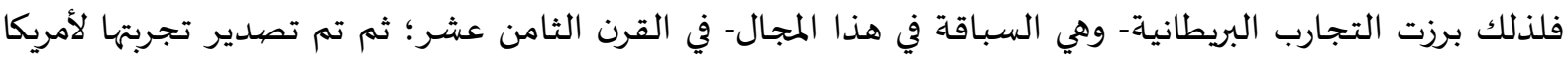
واليابان، وأصبحت الأخيرة منارة يُقتدى بها في عصرنا الحاضر في مجال الاستثمار وتنوع مصادر تمويل التعليم

.(Opoczynski, 2016)

وقد لجأت كثير من الجامعات العالمية لتنويع بدائل تمويلها، من خلال الاستثمار في مواردها وإمكاناتها المادية،

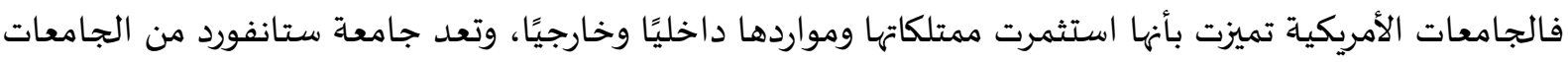

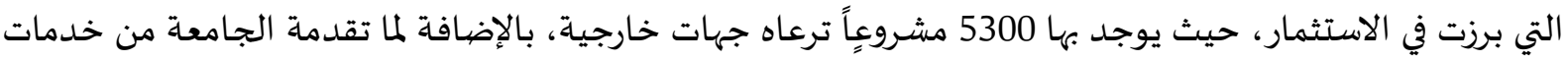


التشغيل الصبي والنهضة الاقتصادية لمجتمعها المحلي، وكذلك الجامعة الاستثمارية (حاضنة اوستن التكنولوجية)

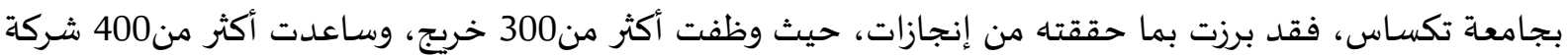

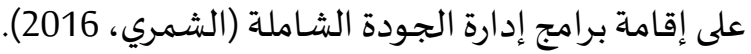

أما في الوطن العربي فقد أشار تقرير اليونسكو (2018) إلى وجود ضعف في بدائل تمويل التعليم العالي، مما

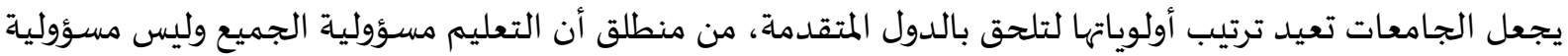

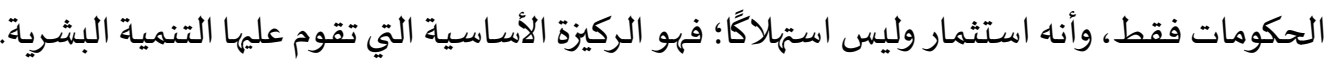
ويقوم تمويل التعليم العالي في المملكة العربية السعودية بالاعتماد شباه الكامل على الدعم الحكومي، وقد خصصت الموازنة العامة 2020 ما يقارب 193 مليار ريال لقطاع التعليم، إلى جانب ذلك تعد المملكة أكثر دول الخليج

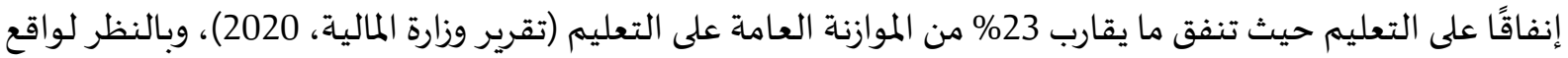

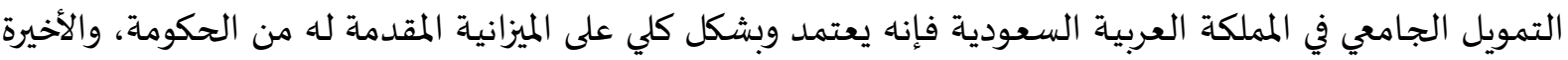
تعتمد على الثروة النفطية غير الدائمة (الدمخ وآخرون، 2019).

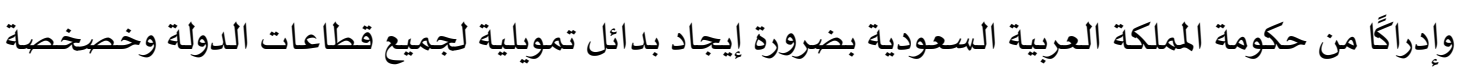
بعض الخدمات، وتفعيل مبدأ الاستثمار في القطاعات الحكومية، كان الهدف السابع من الأهداف الاستراتيجية لوزارة

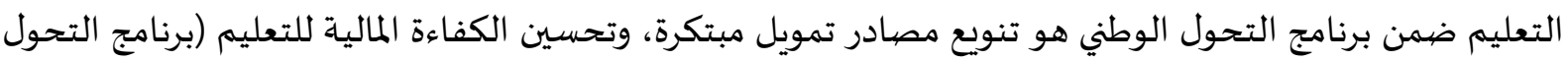

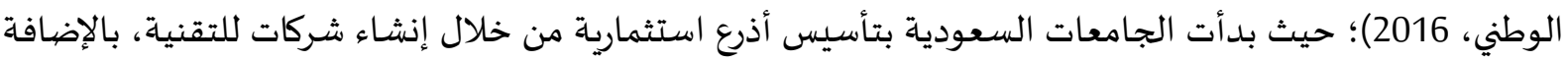

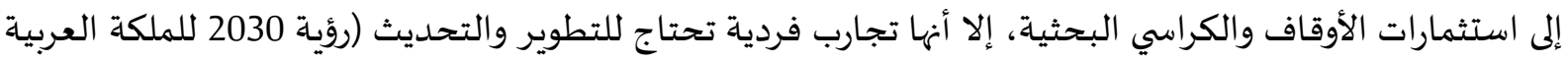

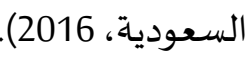

وبالإضافة لما سبق؛ فالوضع الراهن للاقتصاد العالمي والاقتصاد السعودي على حلِّ سواء، وتذبذب أسعار

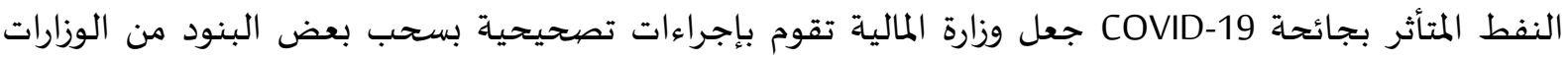

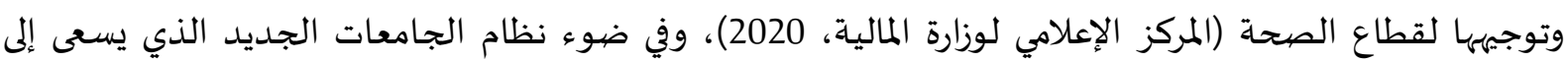

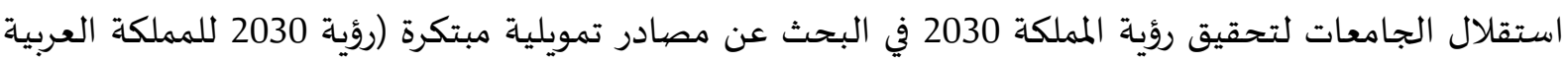

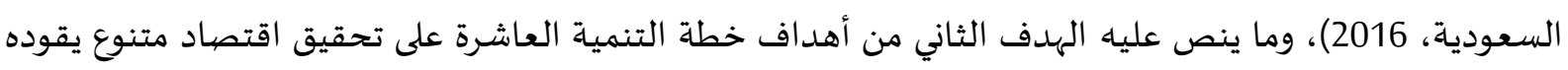

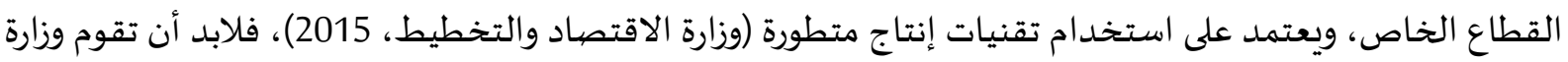

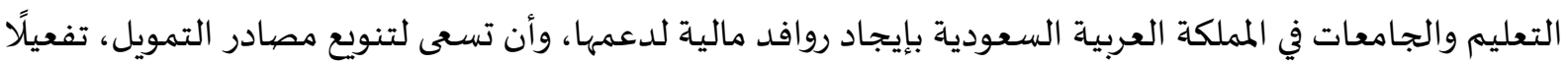
لدور وإسهام القطاعات غير الحكومية في تمويل وتطوير مؤسسات التعليم العالي بالمملكة العربية السعودية (وزارة التعليم العالي، 1432).

ويعتمد تمويل التعليم العالي في المملكة العربية السعودية بشكل كبير على الدعم الحكومي، وتؤكد دراسـة (المنقاش، والسالم، 2018) زيادة ارتفاع تكاليف التعليم العالي؛ نتيجة للزيادة السكانية والاهتمام بالتوسع الكمي لمئي والنوعي، حيث تمثل تحديات للجامعات في جودة مخرجاتها، لذا ظهرت الحاجة في البحث عن الحلول الإبداعية، نائ،

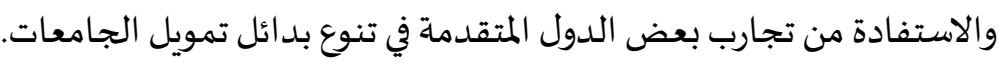

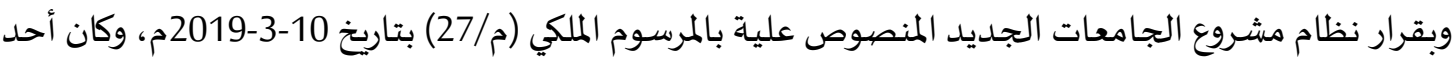

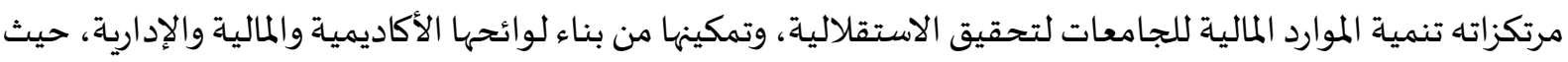

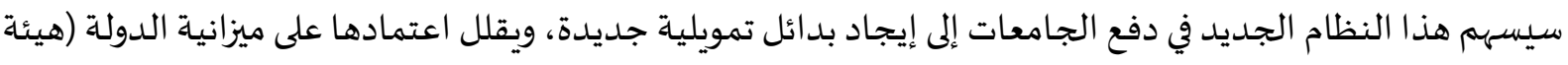
الخبراء بمجلس الوزراء، 2019)، ومن نتائج هذا القرار إعلان وزير التعليم الدكتور حمد آل الشيخ في تصريح له في 16 
يوليو 2020 باستقلال ثلاث جامعات، (الملك سعود، الملك عبدالعزيز، الإمام عبد الرحمن الفيصل) وهي بمثابة المرحلة

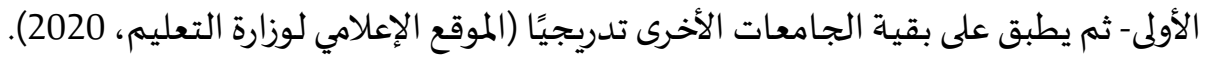

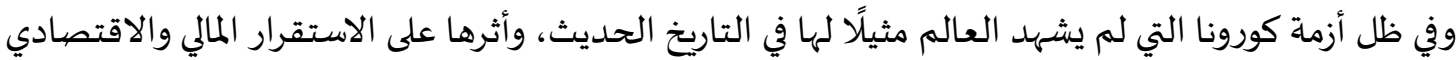

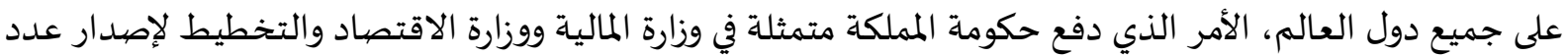
من القرارات والإجراءات للحد من تفاقم الأثار السلبية للأزمة، التي كان من أبرزها إلغاء وتأجيل بعض البنود والنفقات التشغيلية والرأس مالية لعدد من الجهات الحكومية والتي وفرت بدورها 100 مليار ريال، وتم ضخها لزيات لزيادة الاعتمادات لقطاع الصحة لدعم القدرات الوقائية والعلاجية والاحتياجات الطارئة للخدمات الصنات الصحية (وزارة المالية، 2020)

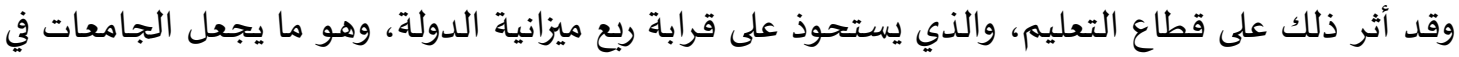

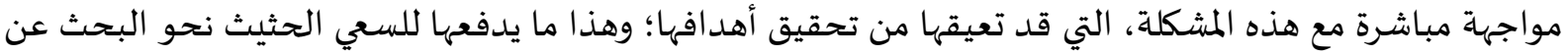
مصادر تمويلية بديلة؛ لسعد العجز الذي قد يؤثر على ميزانية الجامعة،، على المدى القصير أو المتوسط في ظله اهل استمرار الجائحة.

وعلى الرغم من وجود محاولات لبعض الجامعات لإيجاد بدائل غير حكومية لتمويل أنشطتها وبرامجها، وزيادة

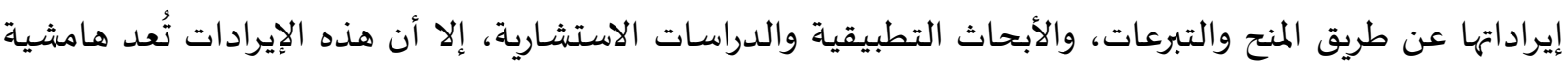

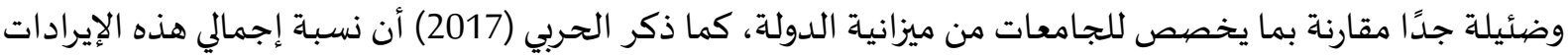

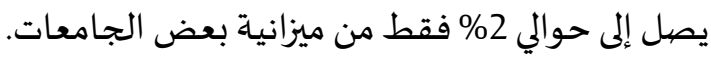

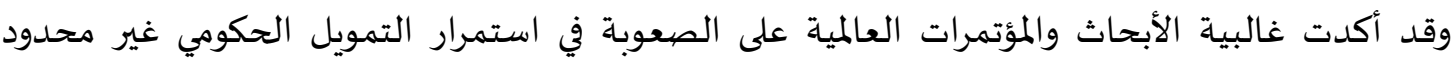

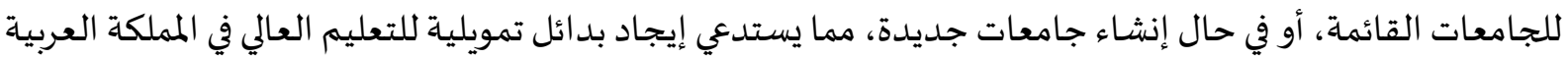
السعودية (العقيل والعيسى، 2019). ومن هنا تتأكد ضرورة البحث عن مصادر متنوعة لتمويل التعليم، وذلك يعد أكثر أمانًا من الاعتماد على

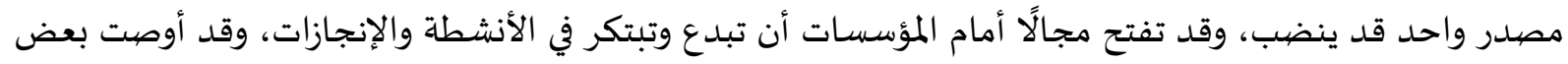

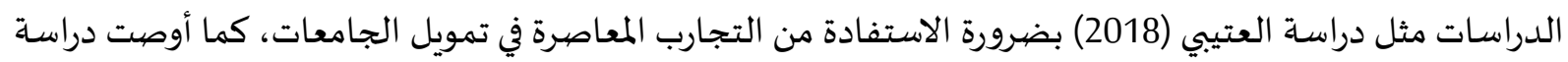
الفراج (2020) بأهمية إنشاء علاقات تعاونية بين الجامعات ومؤسسات المجتمع الإنتاجية.

مشكلة الدراسـة: - مش التعليم العالي في السعودية يحظى بموازنات حكومية عالية، مما يوفر مورداً مالياً يغني الجامعات عن الاستثمار

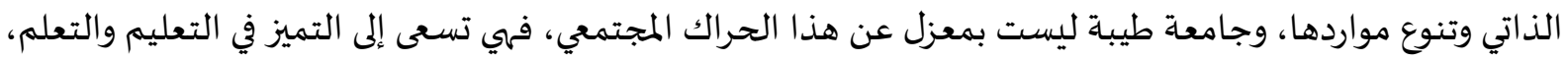
وتطوير البحث العلمي والدراسات العليا لخدمة قضايا المجتمع، وبناء شراكات حقيقية مع المجتمعع، والارتقاء بمكانتها

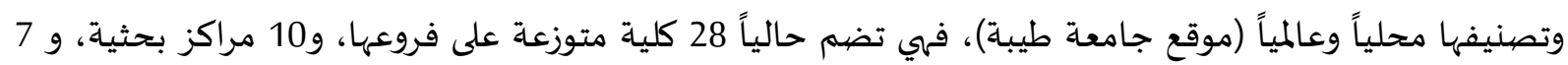

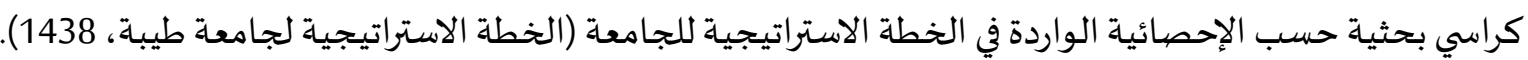

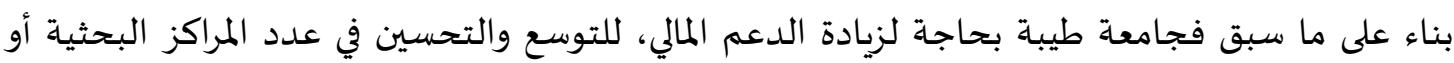

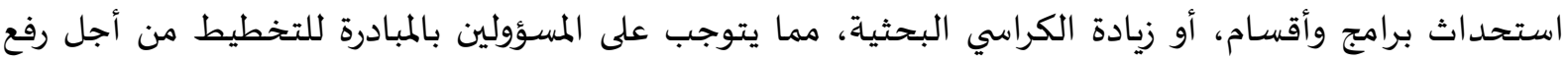
المخصصات المالية للوحدات والمراكز في الجامعة، حتى تحقق القدرة الذاتية في التمويل.

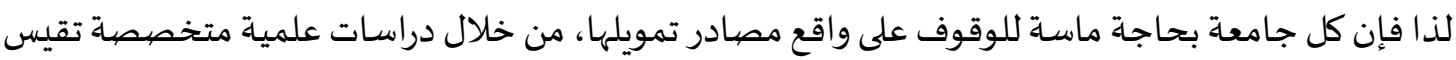

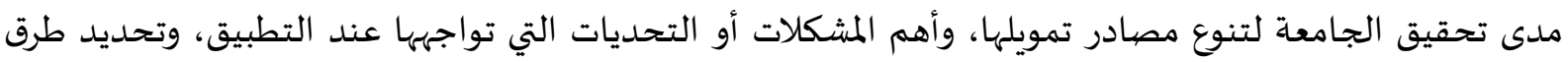

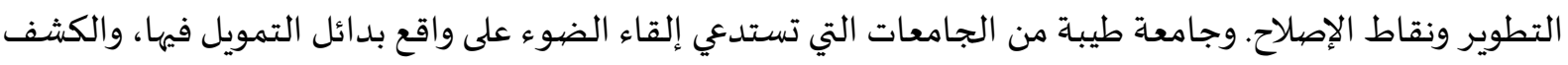


عن التحديات التي تعيق تنوع تمويلها الذاتي، وطرح بدائل مقترحة لتنويع مصادر التمويل في جامعة طيبة في ضوء تجارب بعض الدول المتقدمة.

أسئلة الدراسـة:

بناء على ما سبق؛ يمكن بلورة مشكلة الدراسـة في الأسئلة البحثية التالية:

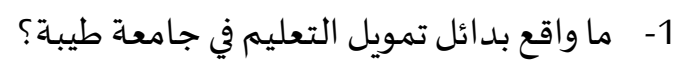

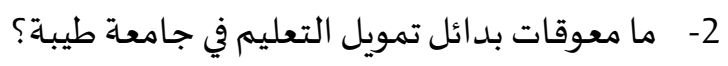

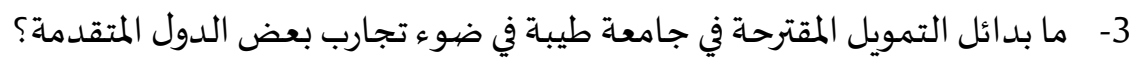

أهداف الدراسـة

تهدف الدراسة إلى تحقيق الآتي:

1. التعرف على واقع بدائل تمويل التعليم المتوفرة في جامعة طيبة الاتية.

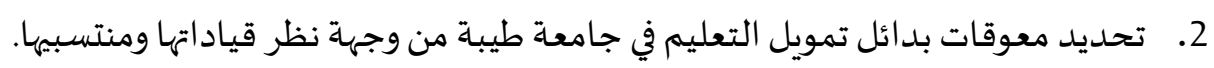

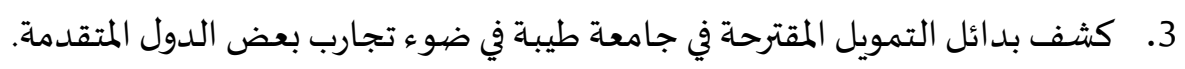

أهمية الدراسـة

تكمن أهمية الدراسة الحالية في مواكبتها لتوجهات رؤية 2030 في تنويع مصادر التمويل للجامعات، كما

تكتسب أهميتها من أهمية موضوع تمويل التعليم؛ حيث تعد قضية مهماه وأساسية لتجويد التعليم وتطويره، ومن هنا

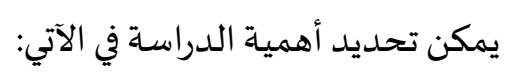

قد تسهم نتائج هذه الدراسة في الكشف عن واقع بدائل تمويل التعليم العالي، وتفيد إدارة الجامعة وصُّناع القرار في التعرف على نواحي القوة والضعف في سياستهم الجامعية تجاه تنوع مصادر التمويل، ومن ثم وضع الحلون

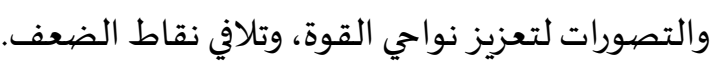

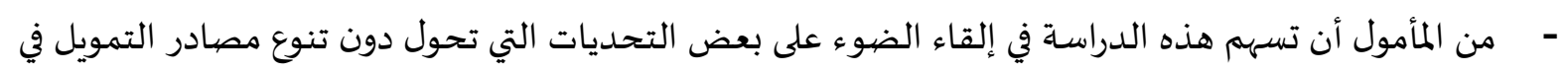
الجامعة، مما قد يفيد أصحاب القرار؛ للعمل على تلافيها.

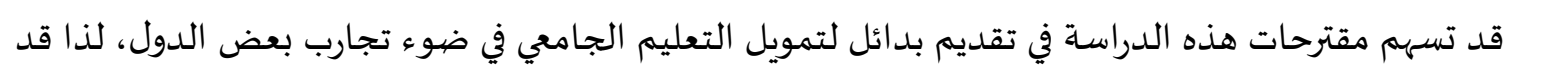

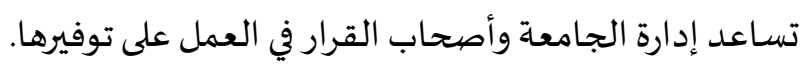

حدود الدراسـة:

اقتصرت الدراسـة على الحدود الآتية:

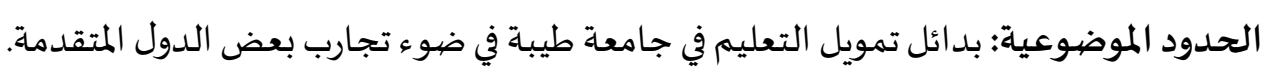

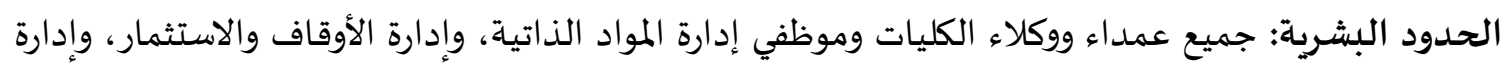
التخطيط والميزانية، وأعضاء هيئة التدريس.

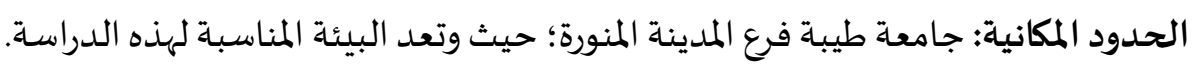
الحدود الزمانية: تم تطبيق الدراسـة في الفصل الثاني من العام الدراسي 1442 هـ 
- مويل التعليم العالي: يُعرف مصطلح تمويل التعليم العالي بأنه "مجموعة الموارد المالية المخصصة لمؤسسات

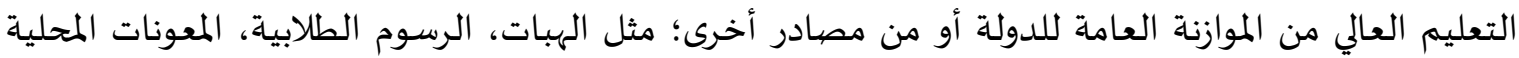

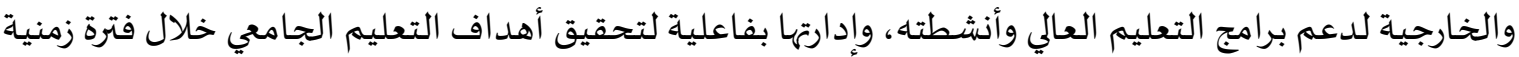

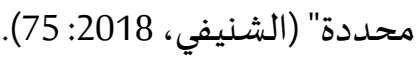
O ميُعرف إجرائيًا بأنه: "مجموعة الموارد المالية التي تخصص للجامعات، من مصادر حكومية أو من مصادر ذاتية، أو

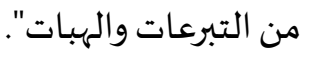

بدائل تمويل:يُعرف مصطلح بدائل تمويل بأنه "طرح أكثر من مصدر واحدبات لتمويل الجامعات السعودية، والتي

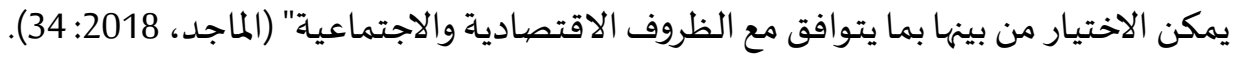

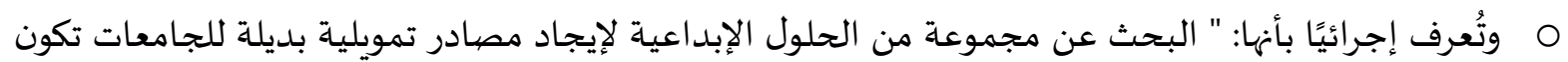

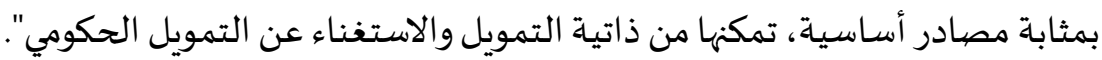

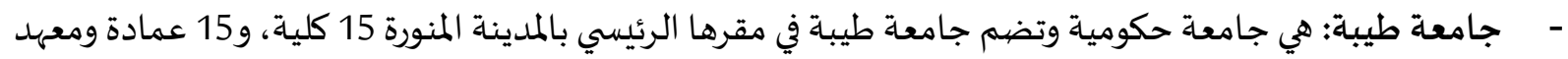
مساند، كما تضمى 10 مراكز بحثياة، و18 مراكز مساندة.

\section{2. الإطار النظري والدراسـات السـابقة.}

يعد التمويل الجامعي من القضايا المهمة للسياسيين والاقتصاديين والتربويين وصناع القرار؛ نظرًا للإقبال

المتزايد على الطلب للالتحاق بمؤسسات التعليم الجامعي، مما يلزم مؤسسات التعليم العالي بتطوير استراتيجياتها

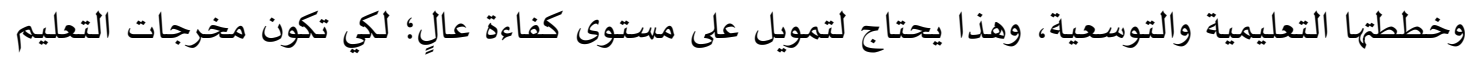

جيدة (الرحيلي، 2019).

يتميز تمويل التعليم العالي عن غيره بالتنوع في بدائله التمويلية التي تعتمد عليها الدول لتيسير عملية التعليم

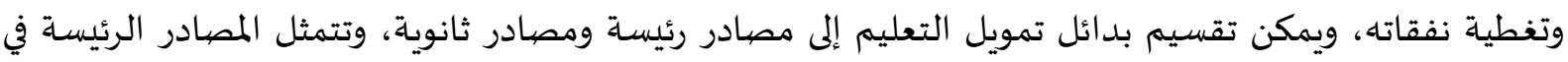
التمويل الحكومي الذي توفره الدولة للتعليم، وذلك من منطلق توفير فرص التعليم للجميع، ومبدأ العدالة وتكافؤ تفولئ الفرص (عيسان، 2016).

وتشتمل المصادر الثانوية على الرسوم الدراسية، وهي أحد المصادر التي من خلالها تحصل المؤسسات

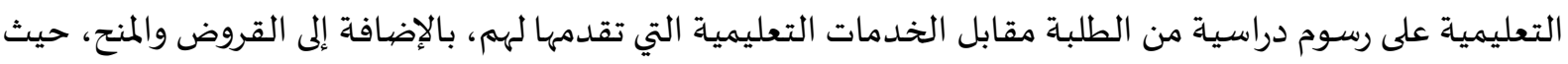

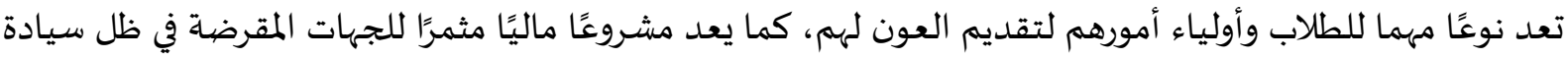
نظرية أن التعليم استثمارٌ وليس استهلاكًا (الجميعي، 2015). بالإضافة إلى الهبات والأوقاف، تأتي الأموال المقدمة من أفراد أو مؤسسات التهاتيات اجتماعياة، على هيئة مساعدات

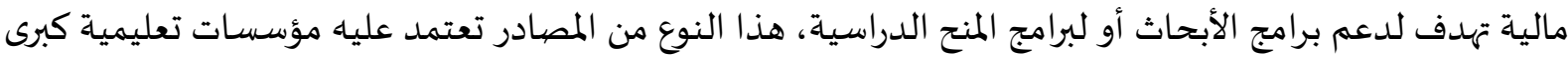

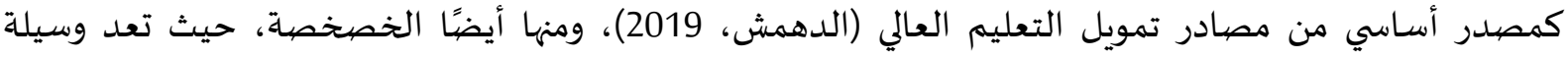

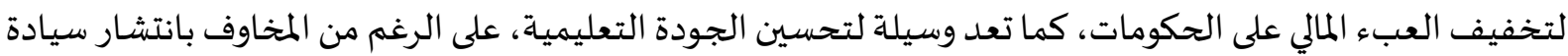
القطاع الخاص- الممثلة بالربحية- على الحكومي؛ مما قد يؤدي لتدني الجودة (الرحيلي، 2019).

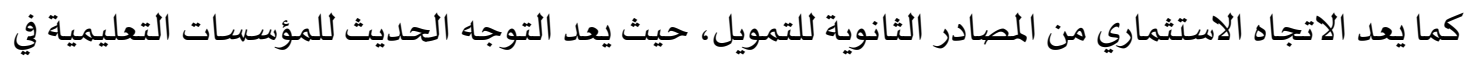

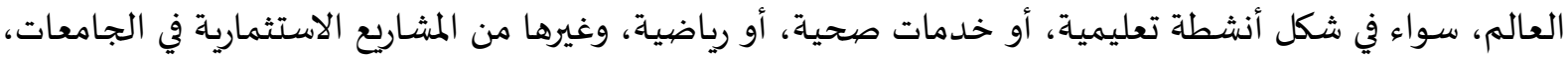


بالإضافة إلى دخل الأوقاف، والمساعدات الدولية، التي تمثل المعونات المقدمة من الدول والمنظمات العالمية إلى الدول المحتاجة لتحقيق أهدافها التربوية (عسيري، 2017).

\section{تمويل التعليم العالي في المملكة العربية السعودية:}

يعد الإنفاق على التعليم في المملكة العربية السعودية مسؤولية الدولة، حيث تشير المادة 233 من وثيقة

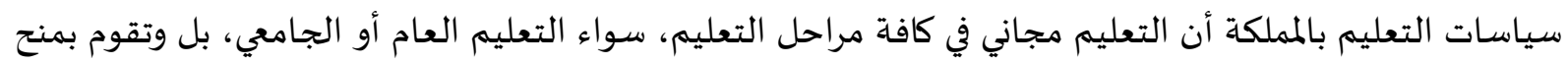

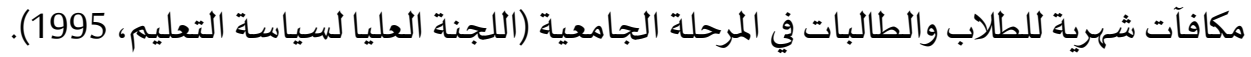
وقد شهد التعليم العالي في المملكة العربية السعودية جهودًا من وزارة التعليم في تنويع بدائل تمويل التعليم

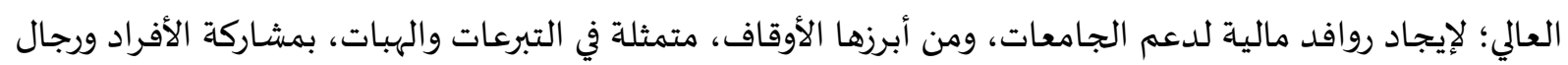

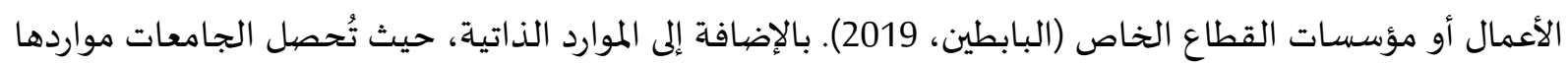

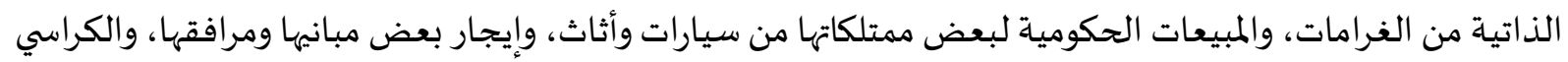

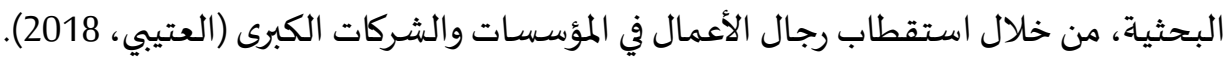

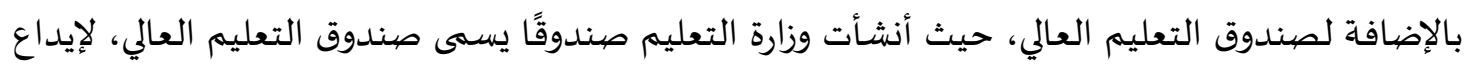

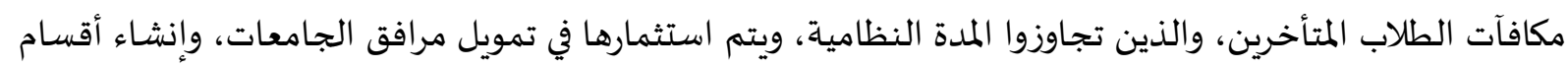

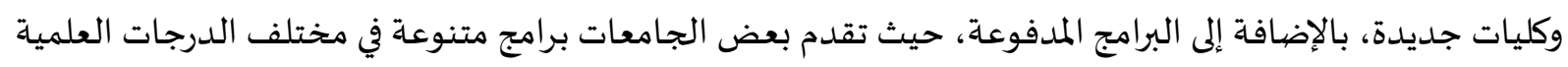

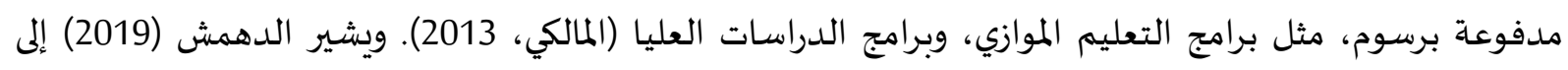

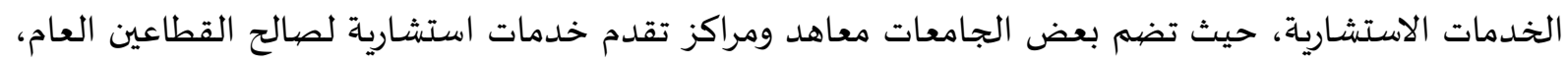
والخاص، يصل عائدها إلى 25\% من ميزانية الجامعة؛ مثل جامعة الملك فهد للبترول والمعادن.

\section{تحديات تنويع بدائل تمويل التعليم العالي:}

يواجه توفير الموارد المالية الكافية لتأمين تعليم مناسب للطلاب كمًا ونوعًا العديد من التحدئ التحيات والمشكلات،

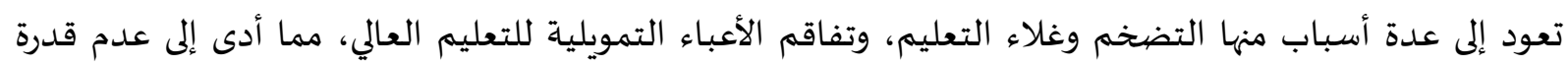

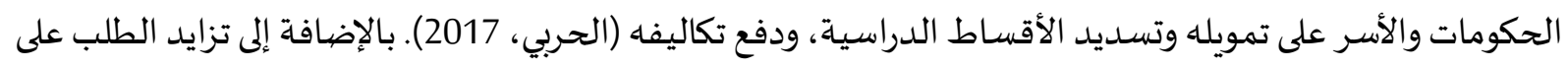

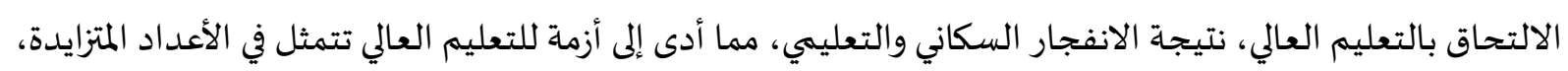
وعدم القدرة على زيادة الطاقة الاستيعابية (الرحيلي، 2019).

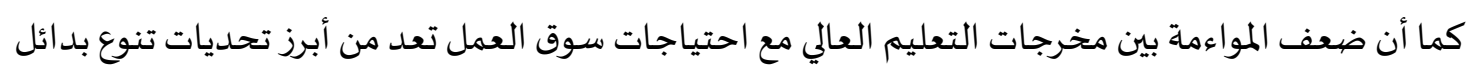

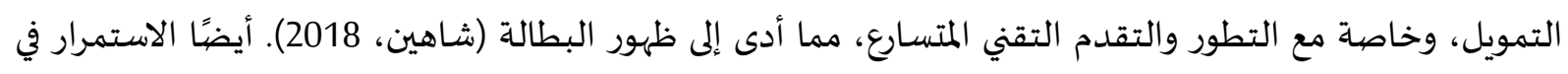

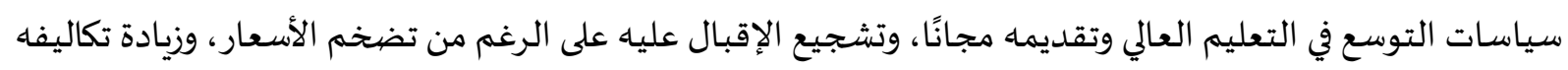
واحتياجاته (حسين، 2011). إضافةً لانخفاض معدلات النمو الاقتصادي، وتأثيرها على انخفاض حجم الموارد التي تدعم ميزانية التعليم،

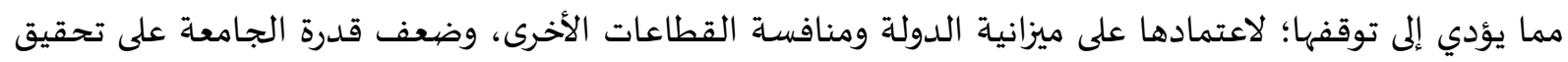

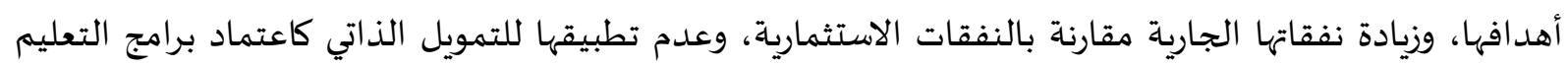

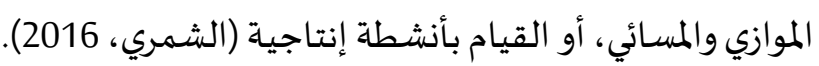


تجارب بعض الدول المتقدمة في تنوع بدائل تمويل التعليم العالي

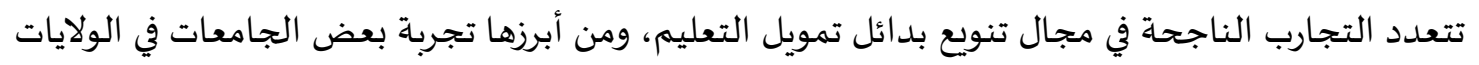
المتحدة الأمريكية، وبريطانيا، واليابان.

بدائل تمويل التعليم العالي في الولايات المتحدة الأمريكية:

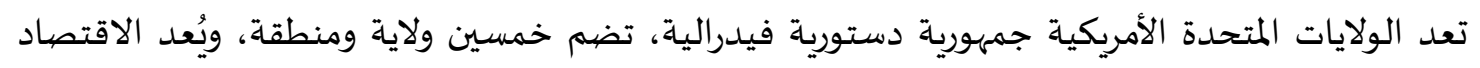

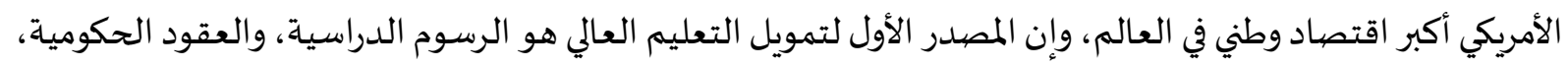

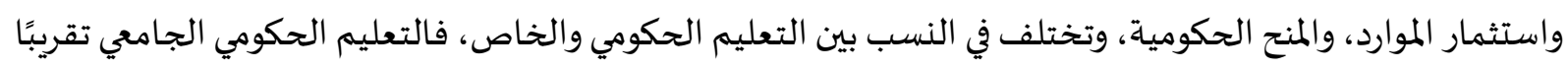

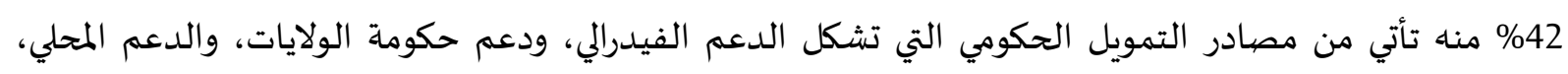

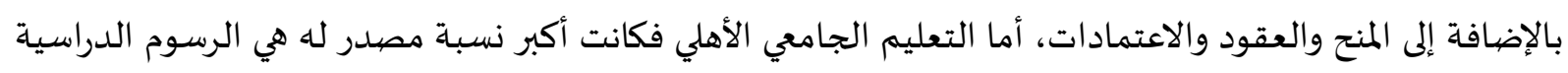
حيث تمثل 90\% تقريبًا من تمويل هذه المؤسسات (Neary, 2019).

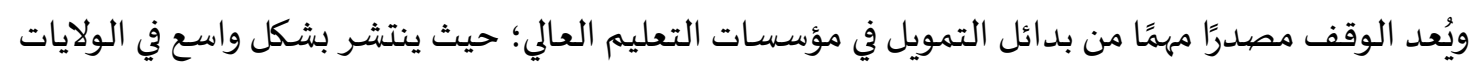

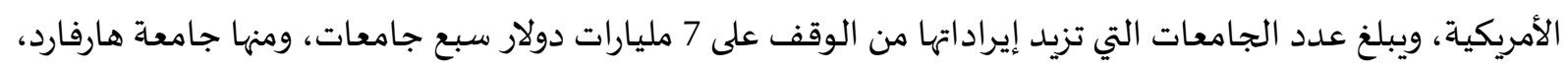

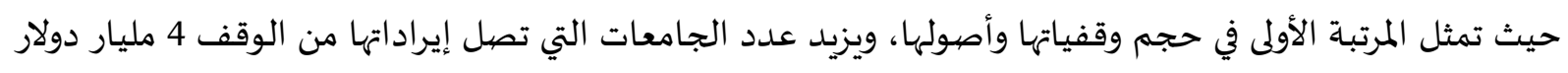

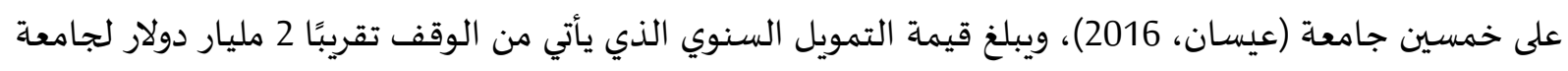

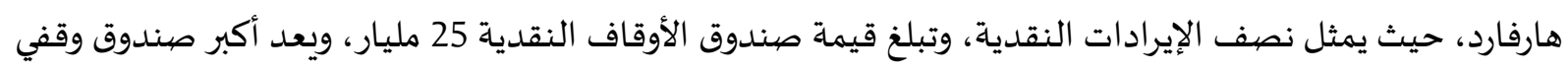
في العالم (Holbec, 2017).

ومن أبرز الجامعات الأمريكية في مجال الجامعة المنتجة جامعة ستانفورد، وقد حققت عدد البحوث التي تقوم

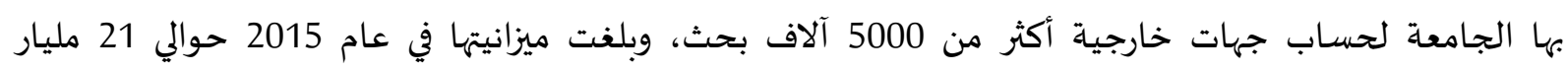
دولار) (Stalowski, 2021). كما برزت جامعة بن ستيت في ولاية بنسلفانيا في مجال الجامعة المنتجاة، وقد بلغت ميزانيتها في عام 2016

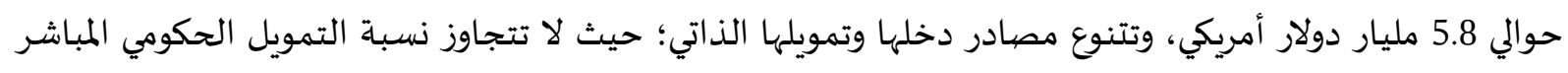

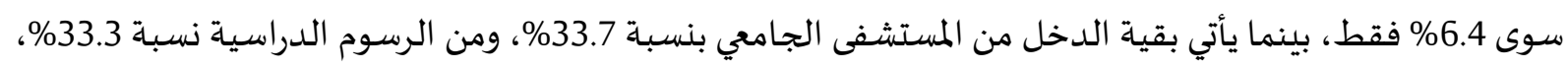

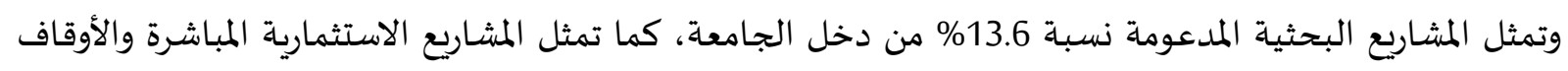

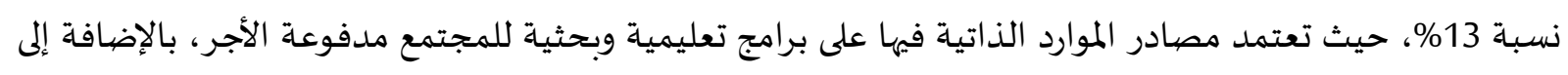

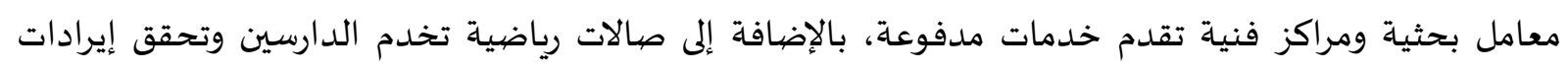
للجامعة (المالكي، 2013).

بدائل تمويل التعليم العالي في بريطانيا:

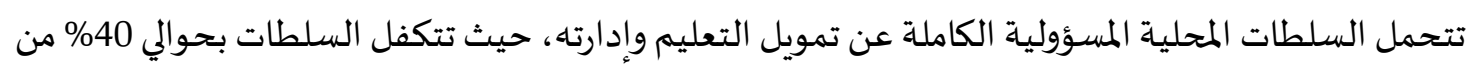

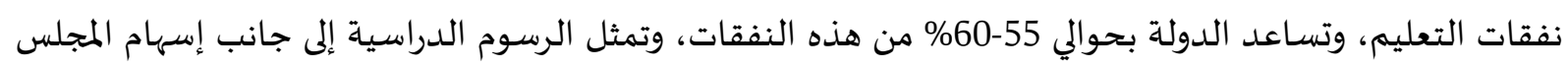

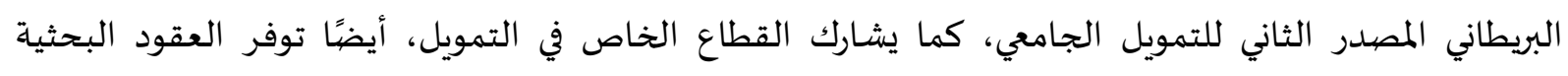
والاستشارات العلمية والهندسية والأوقاف إيرادات إضافية (العتيبي، 2018). ويتوافر في المملكة المتحدة 7 مجالس للبحث العلمي، تقوم الحكومة البريطانية بلدعمها بمقدار 3 مليارات جنية

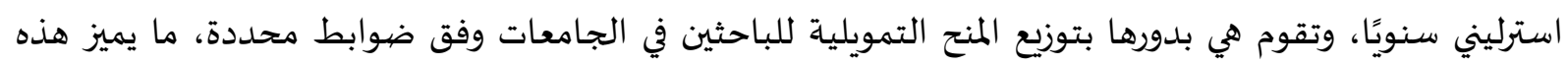


المجالس أها لا تكتفي بدور التمويل فقط، بل تقوم باستشراف النقاط البحثية المهمة في جميع المجالات على مستوى

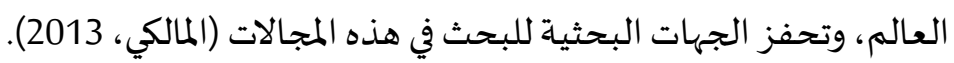

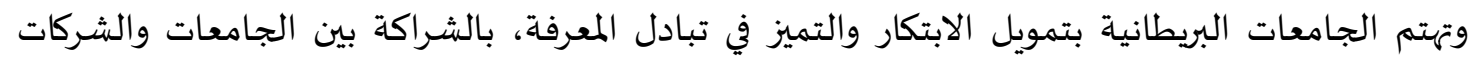

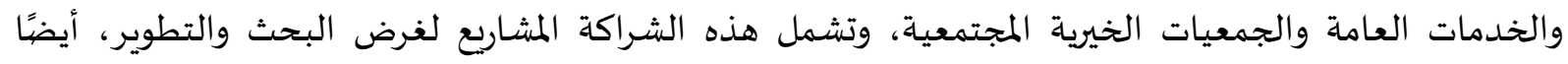

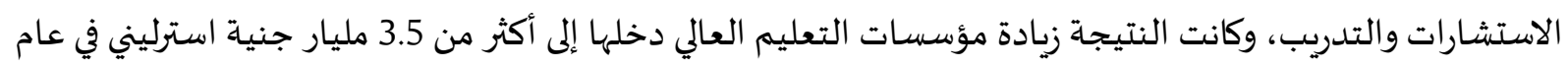
2016 (الدهمش، 2019).

بدائل تمويل التعليم العالي في اليابان: تدعم الحكومة اليابانية تمويل الجامعات القومية بنسبة 75\%، بينما تقدم نسبة الخاصة، حيث تستكمل الجامعات القومية والخاصة باقي نسبة التمويل من مصادرها الخاصة (Akihiro, 2010)،

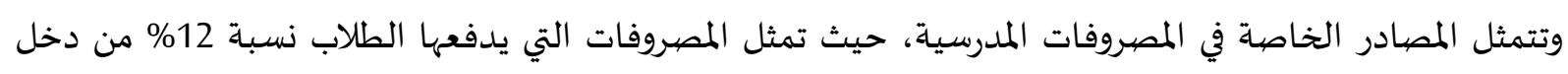

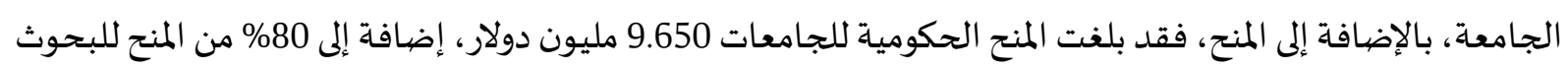

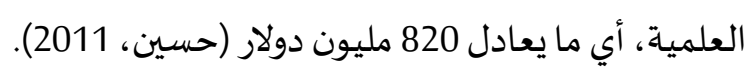
وتقوم الشركات بدور مهم في تمويل التعليم العالي، حيث شاركت ثلاث شركات كبيرة في تمويل التعليم

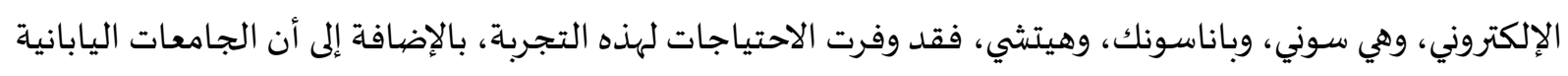

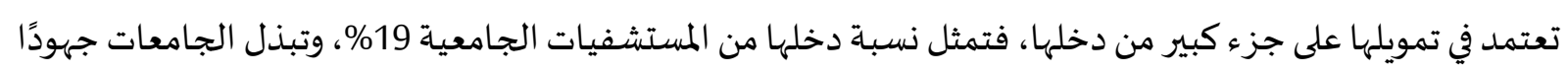

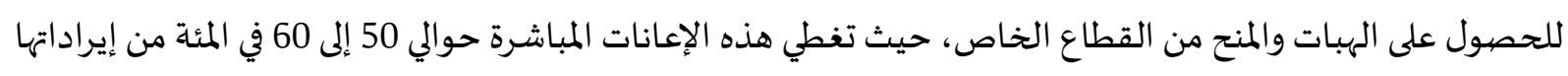
الحالية (عسيري، 2017).

بدائل التمويل في جامعة طيبة: جامعة طيبة هي جامعاة ناشئة تأسست عام 1424-2003 وتسعى إلى بناء مجتمع يعزز التنمية المستدامة واقتصاديات المعرفة، من خلال تعليم وبحوث نوعية وشراكة مع المجتمع، وهي جامعة حكومية شاملة تلتزم بالتميز في

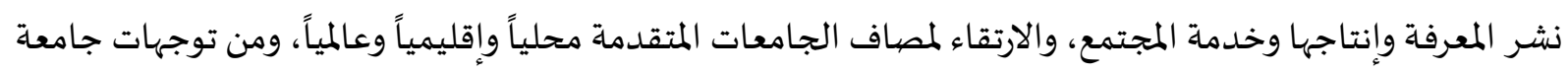

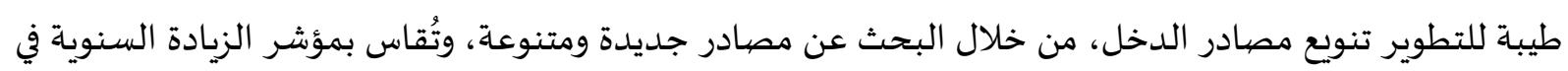

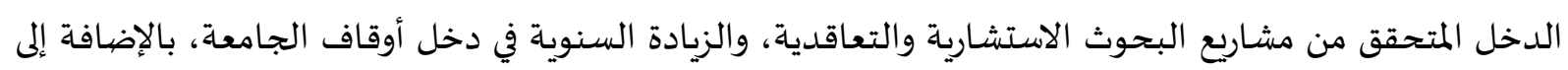

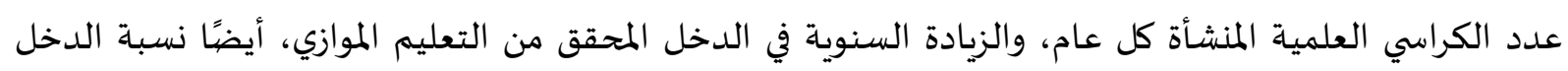

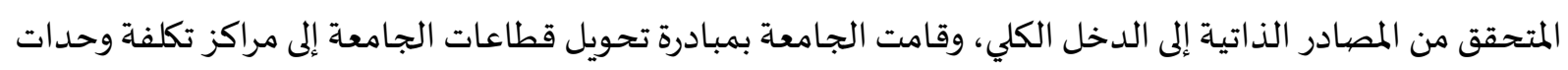

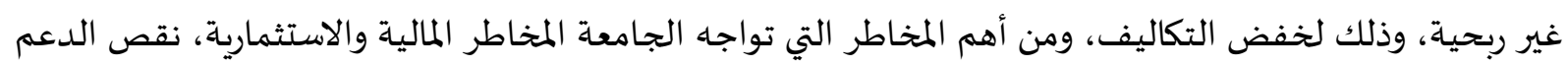

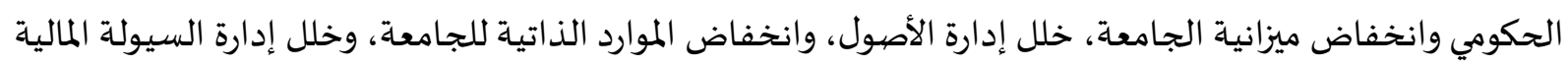
في الجامعة (موقع جامعة طيبة).

ثانياً - الدراسات السـابقة: لقد لاقى موضوع بدائل تمويل التعليم العالي، اهتمامًا عاليًا تمثل في إجراء العديد من الدراسـات، وتم اختيار مجموعة الدراسات الأقرب لموضوع الدراسة الحالية. - - ناقشت الفراج (2020) التحديات التي تواجه تمويل التعليم العالي في المملكة العربية السعودية، والحلول المقترحة للتمويل، استخدمت المنهج الوصفي المستي، بالاعتماد على الاستبانة، وبلغت عينة البحث 23 عميدًا، 
و28 وكيلًا، في مختلف الكليات في جامعة شقراء للعام الدراسي 1441، وتوصلت الدراسة إلى أن أهم التحديات

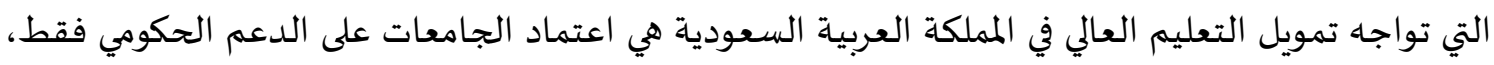

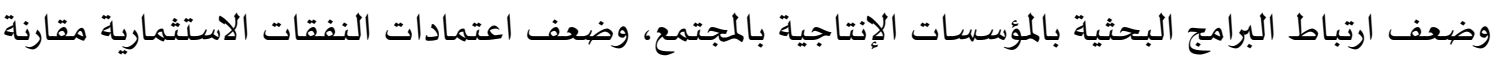
باعتماد النفقات الجارية. وتعرّفت دراسة البابطين (2019) على إمكانية تنويع مصادر تمويل التعليم في المملكة، والوقوف على أبرز

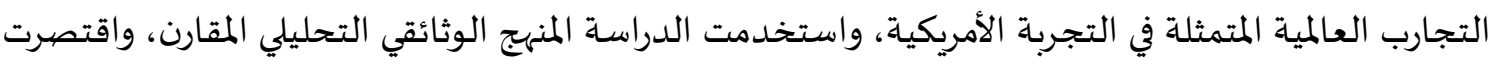

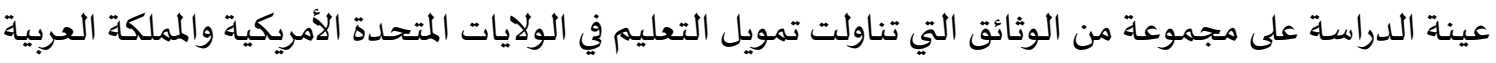

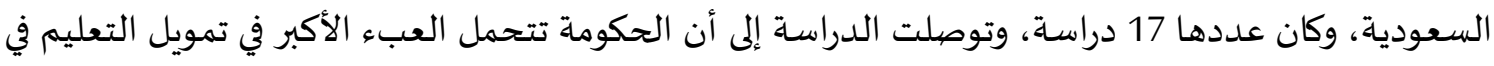

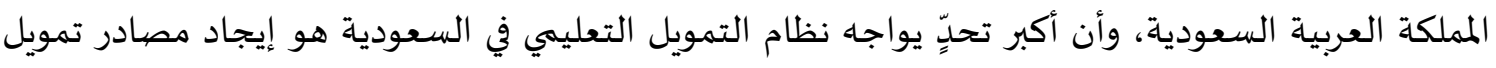
بديلة عن النفط الذي تعتمد عليه الحكومة، وضعف القطاع الخاص في دعم تمويل التعليم، وأن التمويل الأمريكي يسوده الاتجاه الاشتراكي. وهدفت دراسة العقيل والعيسى (2019)، إلى الاستفادة من استراتيجيات تحسين كفاءة التمويل في الجامعات

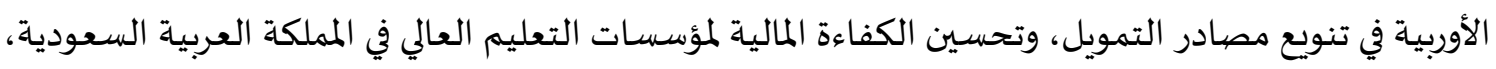

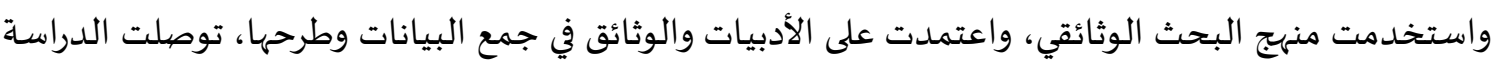

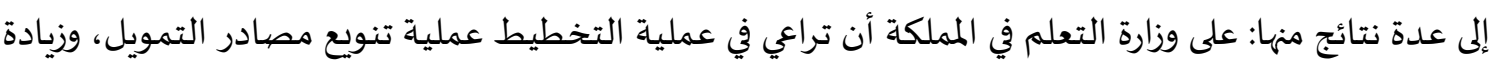
الكفاءة المالية في الجامعات السعودياة.

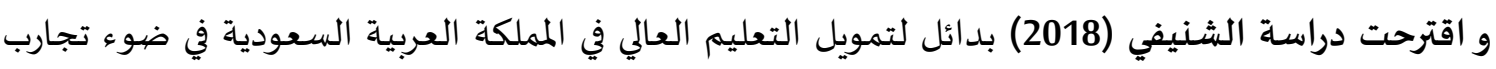

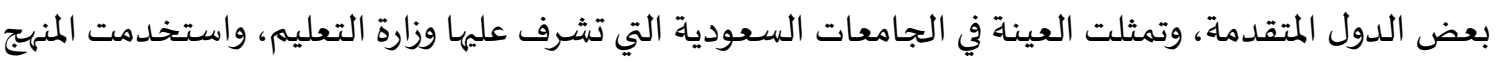

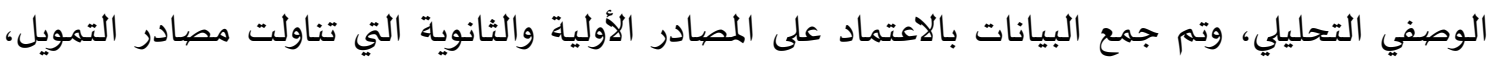

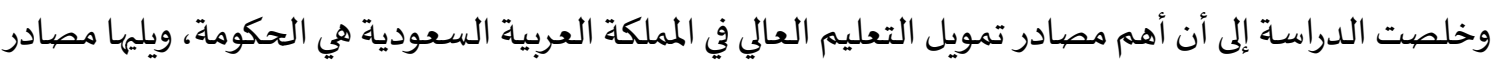

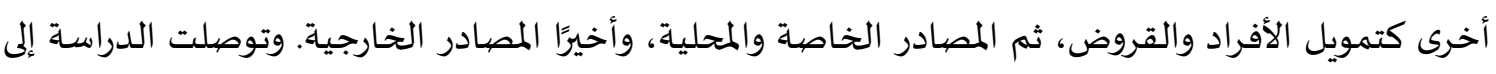

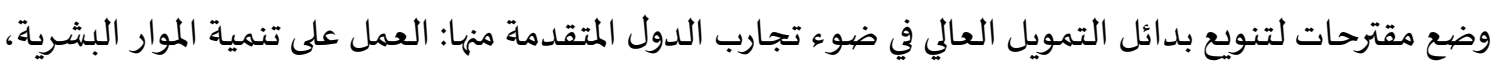

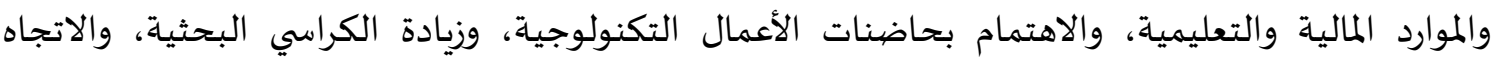
لخصخصة التعليم العالي. وكشف العتيبي (2018) عن واقع تمويل التعليم العالي في كل من أمريكا وبريطانيا واليابان واستراليا، وكيفية

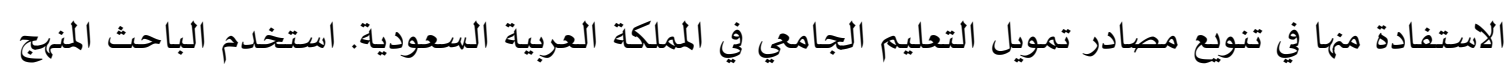

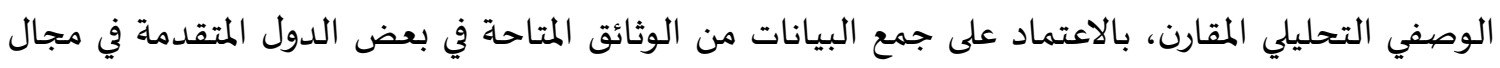

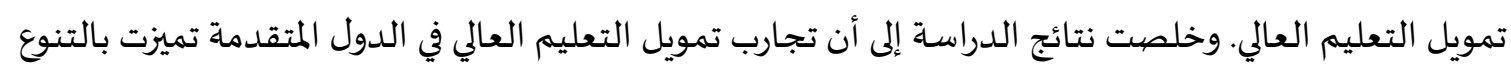

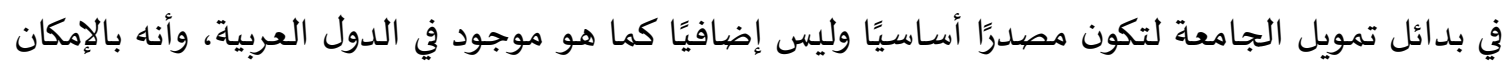

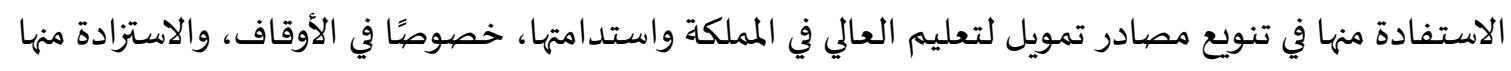
شريطة الاستقلالية والتحرر من قيود البيروقراطية والمركزية.

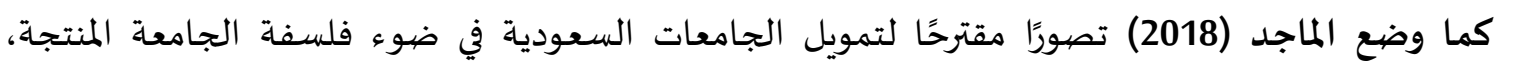

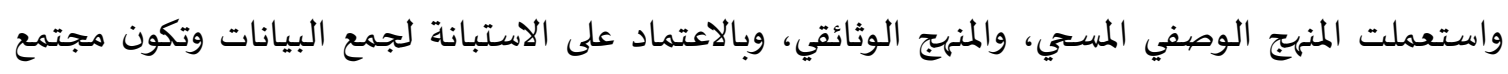

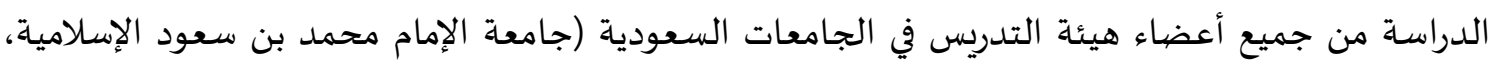

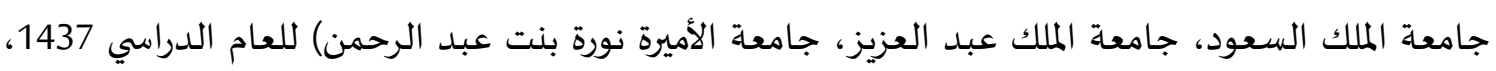


والبالخ عددهم 1006، وتمثلت العينة في 503 من أعضاء هيئة التدريس، وخلصت نتائج الدراسة إلى أنه يجب

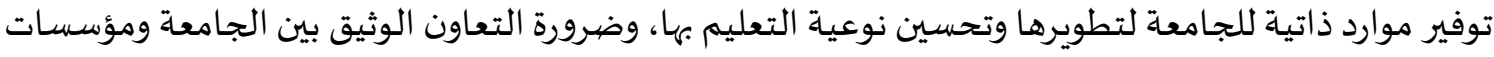

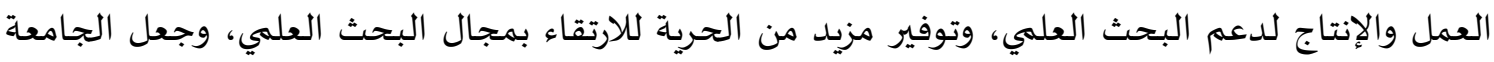
بمثابة بيت الخبرة للمجتمع. ووضع الحافظ وسعد (2018) تصورًا مقترحًا لإيجاد مصادر تمويلية واستثمارية غير تقليدية لجامعة الملك خالد

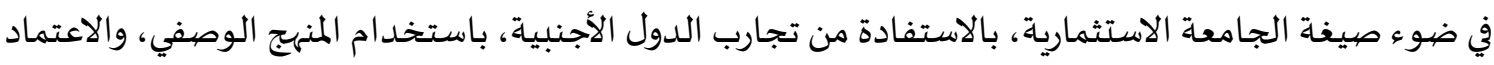

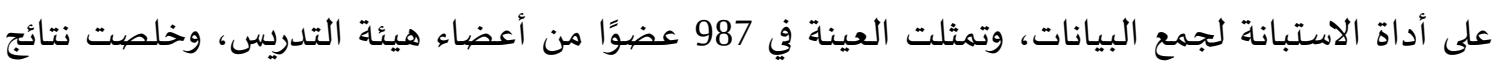

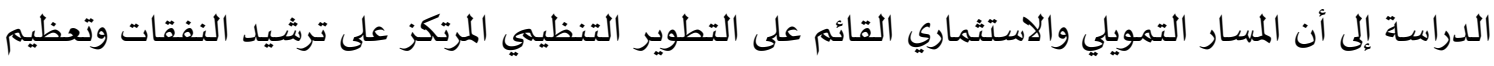

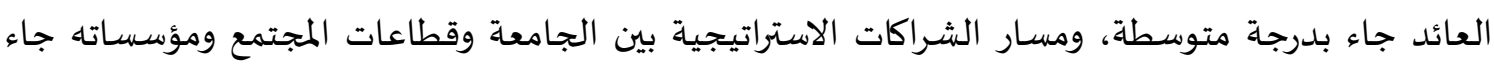

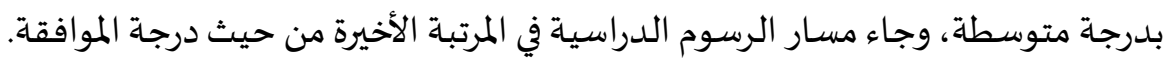

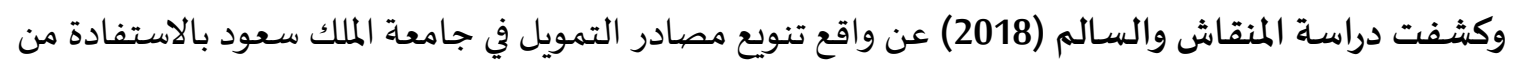

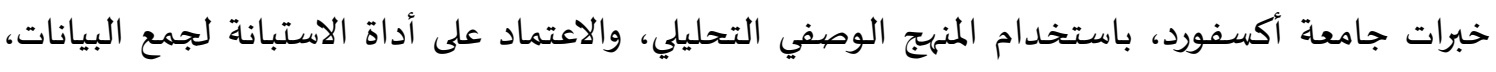

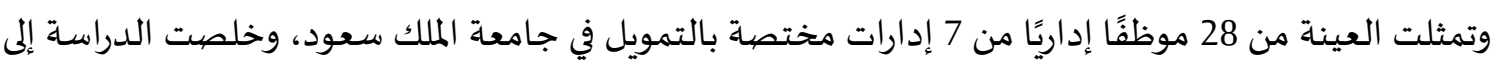

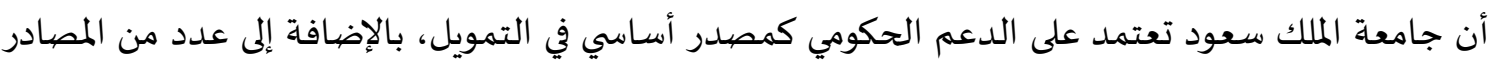

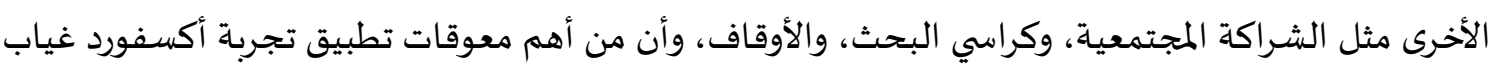

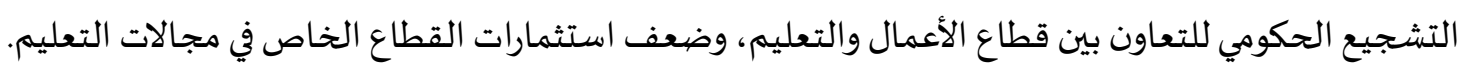

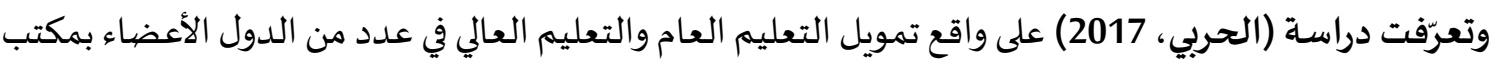

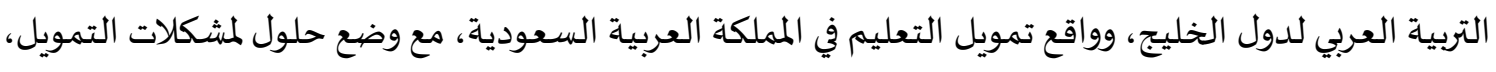

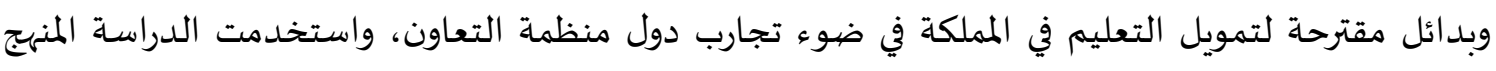

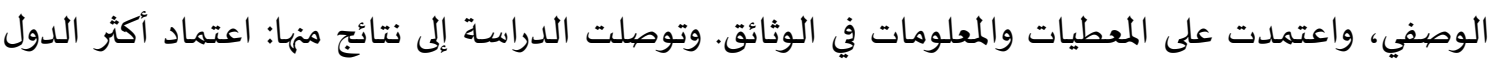

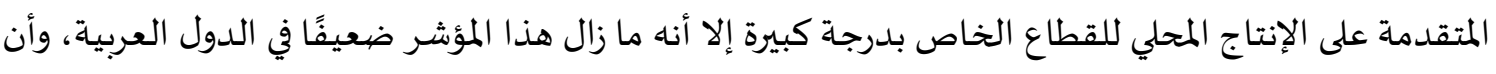

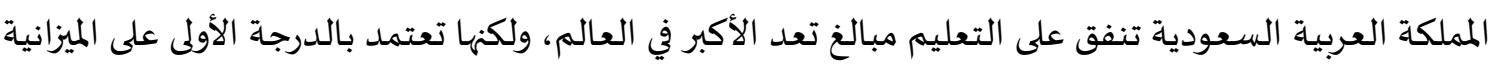

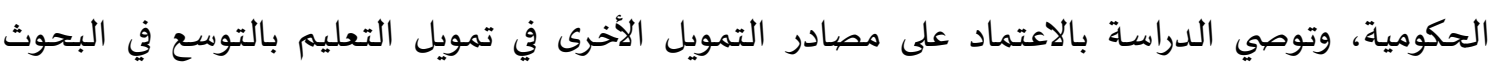

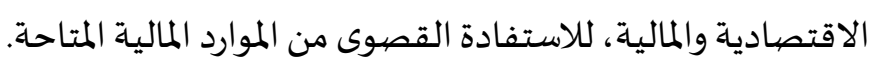

التعليق على الدراسـات السـابقة: تهدف دراسة كلاً من (الشنيفي، 2018) ودراسة (العتيبي، 2018) ودراسة (الحربي، 2015) إلى وضع بدائل

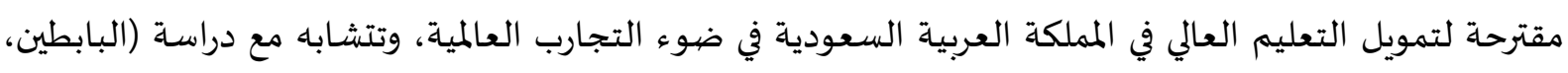

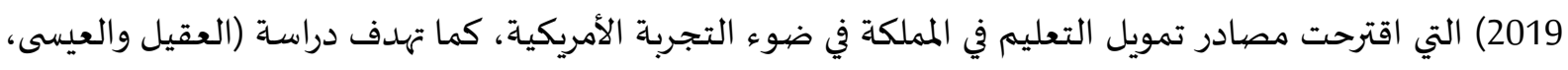

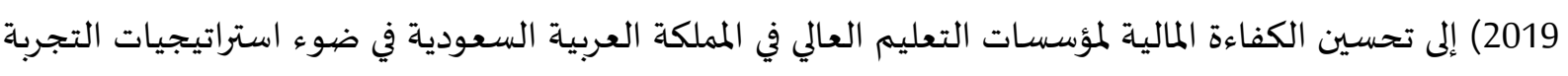

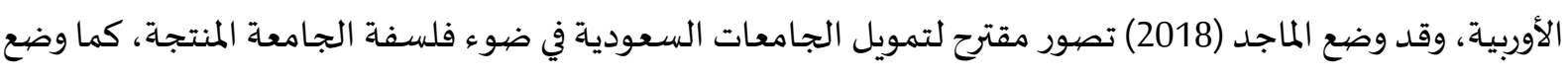

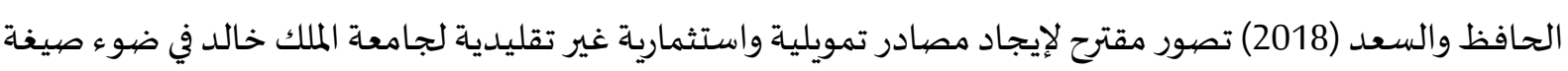
الجامعة الاستثمارية، بينما سعى الفراج (2020) إلى تحديد التحديات التي تواجها تمويل التعليم العالي في المملكة العربية 
تتشابه الدراسات السابقة في استخدامها للمنهج الوصفي، بخلاف دراستا (البابطين، 2019)، والعقيل

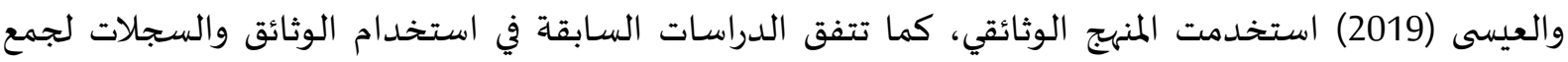

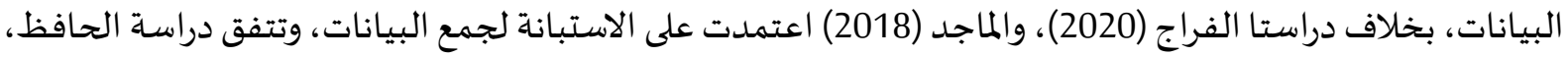

وسعد (2018) ودراسة الماجد في نوع العينة من أعضاء هيئة التدريس، وتتفق في تطبيقها على الجامعات السعودية.

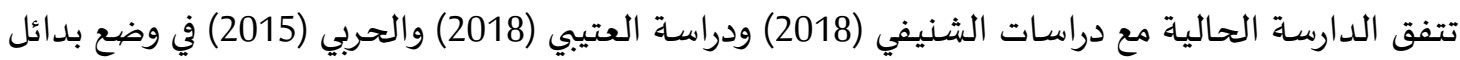
مقترحة لتمويل التعليم العالي في المملكة العربية السعودية في ضوء التجارب العالمية، كما تتفق في المنهج المستخدم،

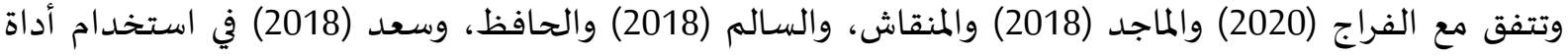

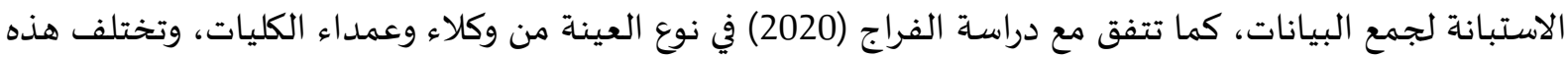
الدراسة في مجتمع الدراسة المتكون في جامعة طيبة.

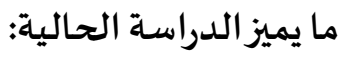
ركزت غالبية الدراسات السابقة على وضع بدائل مقترحة لتنويع مصادر التمويل في التعليم العالي في المملكة في ضوء التجارب العالمياة، بالاعتماد على الوثائق والسجلات، بينما تتميز الدراسة الحالية بالكشف عن واقع التمويل في جامعاة طيبة وذلك من وجهاة نظر العمداء ووكلاء الكليات ومسؤولي الشؤن المالية في الجامعة، وأعضياء هيئة التدريس،

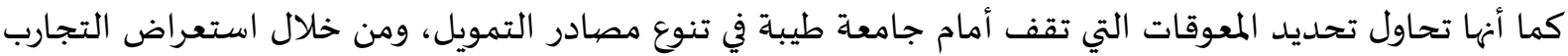

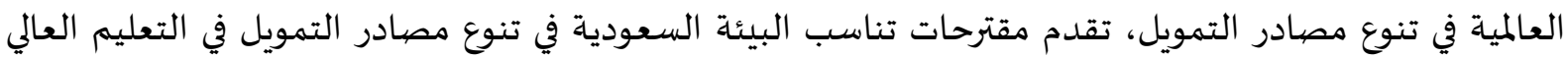
وجامعة طيبة على وجه الخصوص، حيث أنها تعد الدراسة الأولى-على حد علم الباحث- التي تطبق على جلى جامعاة طيبة.

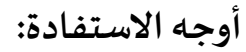
استفادت الدراسة الحالية من الدراسات السابقة في بلورة مشكلة البحث وتحديد الاسئلة البحثية، وبناء أجزاء

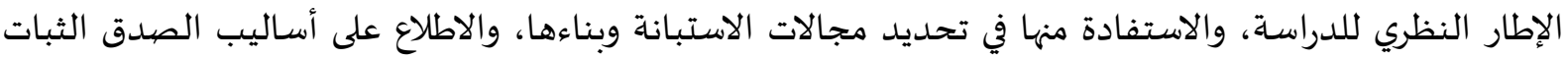

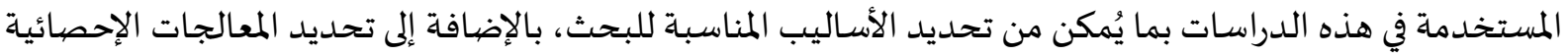

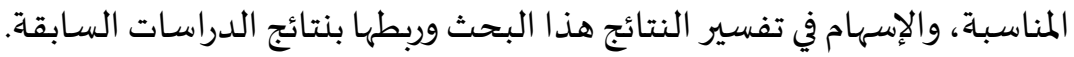

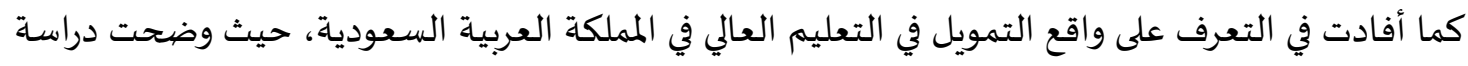

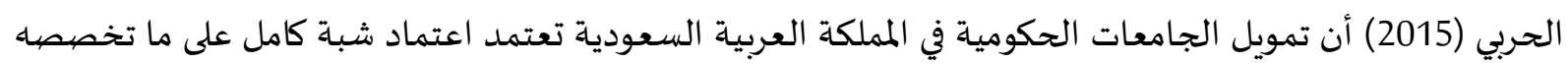

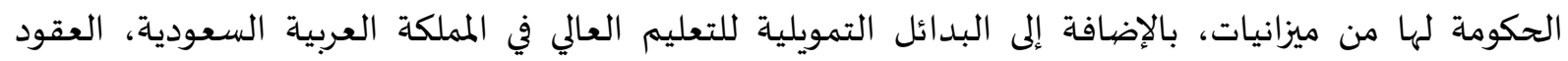
الاستثمارية مع القطاع الحكومية والخاصة، والرسوم الدراسية، ومراكز الأبحاث العلمية.

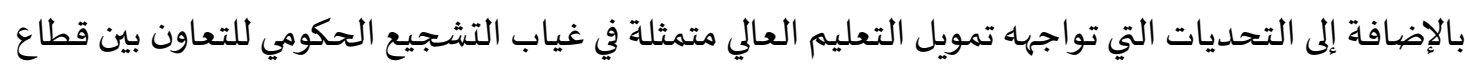

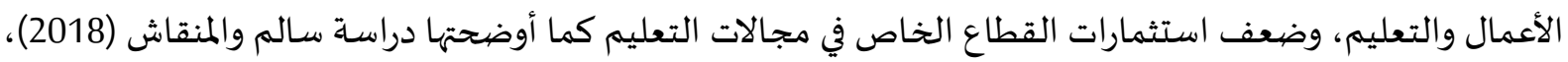
كما أشارت البابطين (2019) إلى أن ضعف القطاع الخماص التماص في دعم تمويل التعليم من تحديات تمويل التعليم العالي في

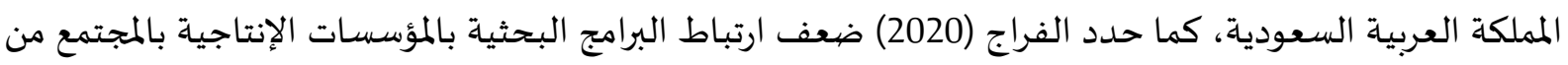
التحديات.

كما أفادت الدراسات في استعراض تجارب الدول المتقدمة في تنوع بدائل التمويل، ووضيع المقترحات التي تناسب

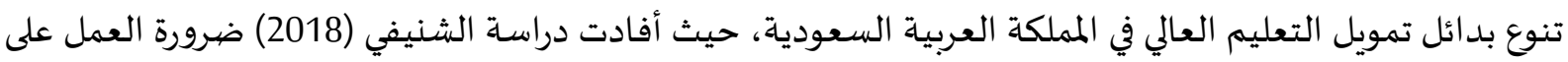

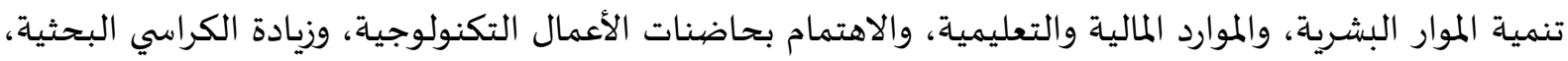
والاتجاه لخصخصة التعليم العالي. 
3. منهجية الدراسة وإجراءاتها.

منهجج الدراسـة:

تستخدم هذه الدراسة المنهج المختلط الذي يجمع بين المنهج الكمي والنوعي في جمع البيانات وتحليليها؛ لمناسبة

هذا المنهج لطبيعة الدراسة الحالية.

مجتمع الدراسة وعينتها:

اشتمل مجتمع الدراسة الأصلي على العمداء والوكلاء وأعضاء هيئة التدريس بجامعة طيبة وموظفي إدارة

التخطيط والميزانية وإدارة الأوقاف والاستثمار وإدارة الموارد الذاتية.

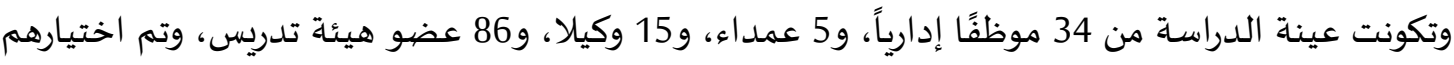

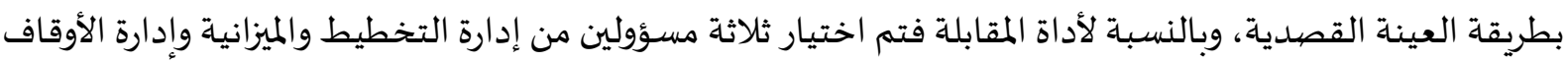

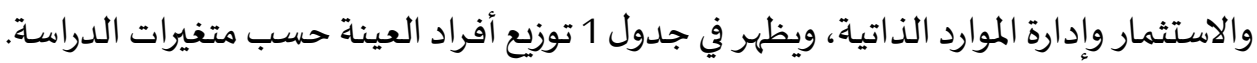

جدول (1) العينة بحسب متغيرات (النوع الاجتماعي - طبيعة العمل - مكان العمل - المستوى التعليمي - الخبرة).

\begin{tabular}{|c|c|c|c|}
\hline النسبة المئوية & 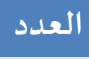 & 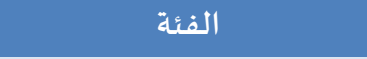 & 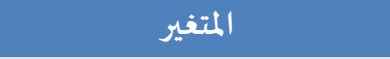 \\
\hline \%69 & 96 & ذكر & \multirow{3}{*}{ النوع الاجتماعي } \\
\hline$\% 31$ & 44 & أنثى & \\
\hline$\% 100$ & 140 & الإجمالي & \\
\hline$\% 4$ & 5 & عميد & \multirow{5}{*}{ طبيعة العمل } \\
\hline$\% 11$ & 15 & 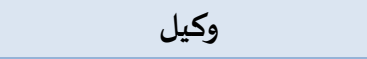 & \\
\hline$\% 61$ & 86 & عضيو هيئة تدريس & \\
\hline$\% 24$ & 34 & موظف إداري & \\
\hline$\% 100$ & 140 & الإجمالي & \\
\hline$\% 4.3$ & 6 & إدارة الأوقاف والاستثمار & \multirow{6}{*}{ مكان العمل } \\
\hline$\% 2.9$ & 4 & إدارة التخطيط والميز انية & \\
\hline$\% 8.6$ & 12 & إدارة الموارد الذاتية & \\
\hline$\% 77.9$ & 109 & الكلية. & \\
\hline$\% 6.4$ & 9 & 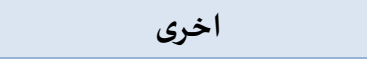 & \\
\hline$\% 100$ & 140 & الإجمالي & \\
\hline$\% 64$ & 89 & دكتوراه & \multirow{6}{*}{ المستوى التعليهي } \\
\hline$\% 14$ & 19 & ماجستير & \\
\hline$\% 18$ & 25 & بكالوريوس & \\
\hline$\% 3$ & 5 & د بلوم & \\
\hline$\% 1$ & 2 & 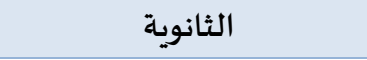 & \\
\hline \%100 & 140 & الإجمالي & \\
\hline$\% 36$ & 51 & 5 سنوات فأقل & \multirow{4}{*}{ سنوات الخبرة في المنصب الحالي } \\
\hline$\% 27$ & 37 & من 6 و أقل من 10 سنوات. & \\
\hline$\% 37$ & 52 & 11 سنة فأكثر. & \\
\hline$\% 100$ & 140 & الإجمالي & \\
\hline
\end{tabular}


يتضح من جدول 1 أن عينة الذكور تمثل ثلثي العينة حيث بلغ عددهم 96 ما بين عميد ووكيل وعضيو هيئة

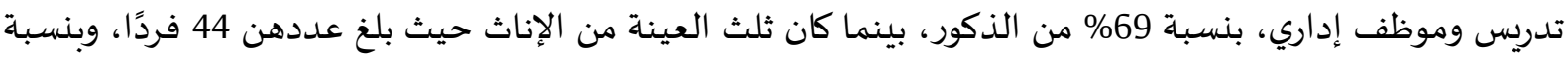

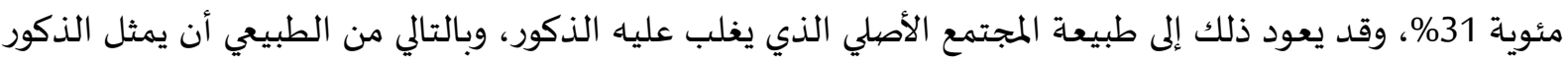
نسبة أعلى في العينة.

$$
\text { أدوات الدراسة وإجراءاتها: }
$$

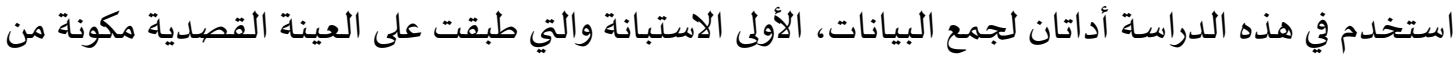

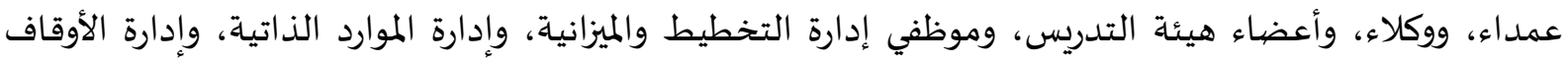

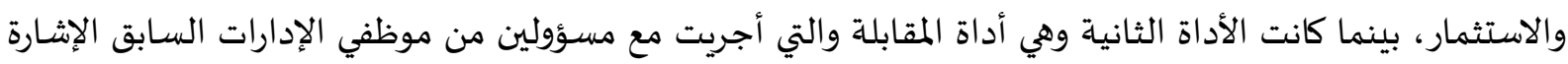
إليهم في جامعة طيبة. الأداة الأولى: الاستبانة: بعد الاطلاع على أدبيات الدراسة والدراسات ذات الصلة بموضوع الدراسة ومتغيراتها،

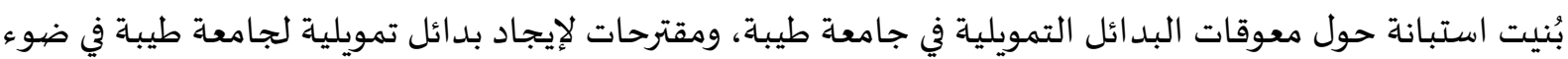

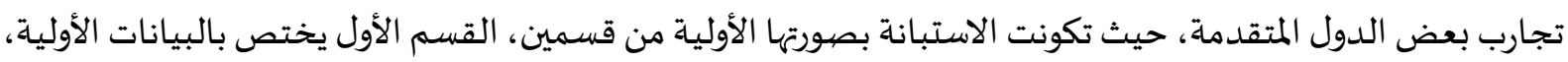

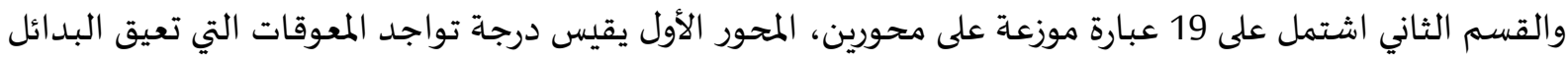

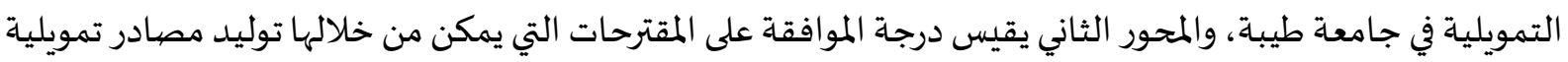
لجامعة طيبة في ضوء تجارب بعض الدول المتقدمة.

صهدق الأداة وثباتها: وللتحقق من الصدق الظاهري للاستبانة تم عرضها على عدد (7) من المحكمين ذوي الخبرة والاختصاص في

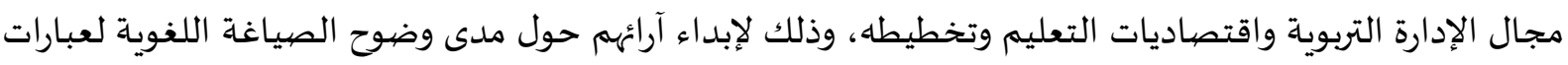

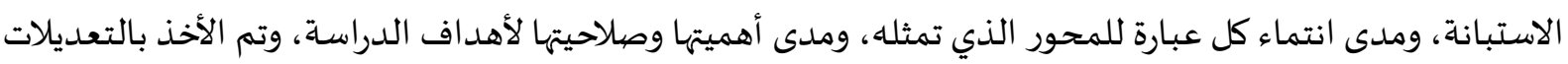
المقترحة التي اتفق عليها 80\% من المحكمين، وبالتالي تكونت الاستبانة بصورتها النهائية من التهائه 19 عبارة.

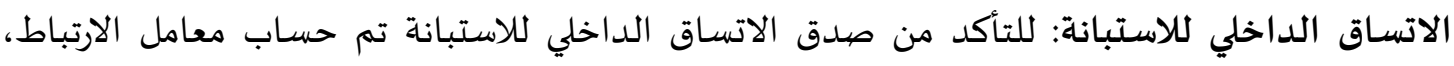

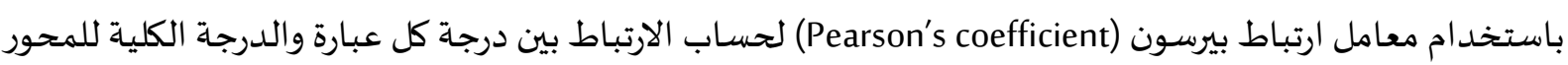

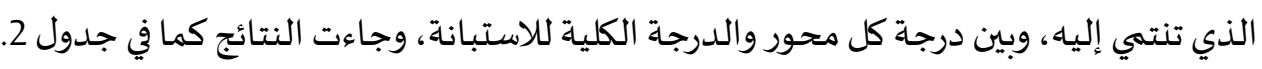

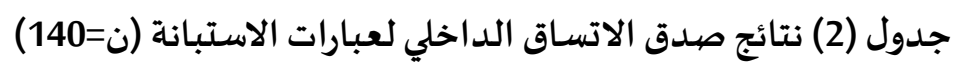

\begin{tabular}{|c|c|c|c|c|c|c|c|}
\hline \multicolumn{3}{|c|}{ نتائج ثبات الاستبانة بطريقة ألفا - كرونباخ } & \multicolumn{2}{|c|}{ المحور الثاني: مقترحات } & \multicolumn{3}{|c|}{ المتحور الأول: معوقات البدائل } \\
\hline معامل الثبات & عدد العبارات & الاستبانة & 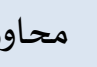 & معامل الارتباط & م & معامل الارتباط & م \\
\hline 0.83 & 9 & حتور الأول & درجة | & 0.39 & 1 & 0.56 & 1 \\
\hline 0.72 & 10 & حور الثاني & درجة | & 0.58 & 2 & 0.73 & 2 \\
\hline \multirow[t]{3}{*}{0.83} & 19 & متبة الكلية & & 0.52 & 3 & 0.79 & 3 \\
\hline & & & & 0.52 & 4 & 0.63 & 4 \\
\hline & & & & 0.59 & 5 & 0.73 & 5 \\
\hline
\end{tabular}




\begin{tabular}{|c|c|c|c|c|}
\hline نتائج ثبات الاستبانة بطريقة ألفا - كرونباخ & 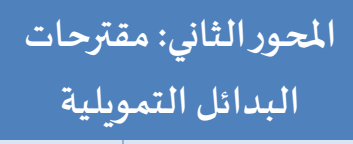 & \multicolumn{3}{|c|}{ المحور الأول: معوقات البدائل } \\
\hline & \begin{tabular}{l|l}
0.63 \\
\end{tabular} & 6 & 0.77 & 6 \\
\hline & 0.60 & 7 & 0.55 & 7 \\
\hline & 0.68 & 8 & 0.63 & 8 \\
\hline & 0.57 & 9 & 0.45 & 9 \\
\hline & 0.41 & 10 & 0.88 & الكلي \\
\hline & 0.80 & الكلي & & \\
\hline
\end{tabular}

يتضح من جدول 2 أن معاملات ارتباط عبارات المحور الأول بدرجته الكلية تراوحت بين 0.45 - 0.79، في حين

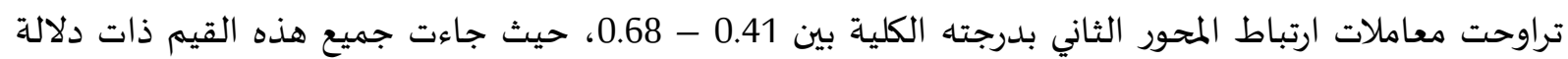

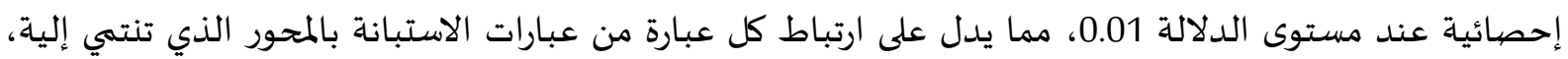

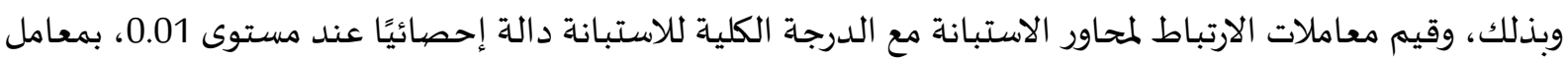
ارتباط 0.88 للمحور الأول، وبدرجة ارتباط 0.80 للمحور الثاني، حيث تمثل معاملات ارتباط مرتفعة، وهذا معا يدل على على أن الن

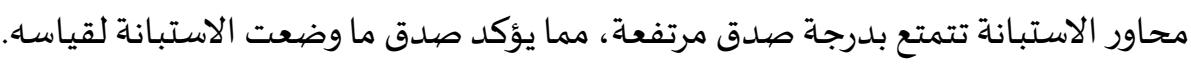

ثبات أداة الدراسـة: لحساب ثبات محاور الاستبانة ودرجتها الكلية تم استخدام معامل "ألفا كرونباخ" وذلك بالاستعانة ببرنامج

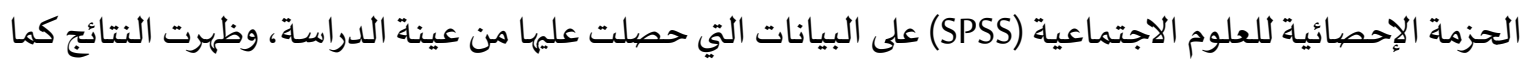

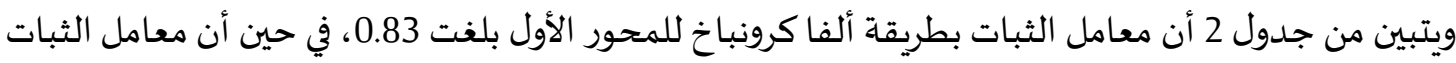

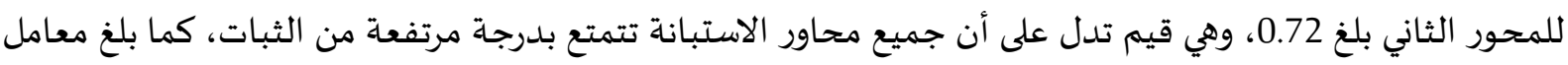

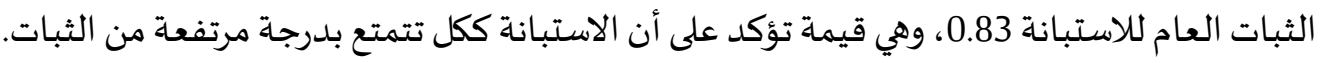

الوزن النسبي والمعالجات الإحصيائية:

تم استخدام مقياس (ليكرت خماسي) لتحديد درجة التواجد بحيث تعطي الدرجة (5) بدرجة كبيرة جداً،

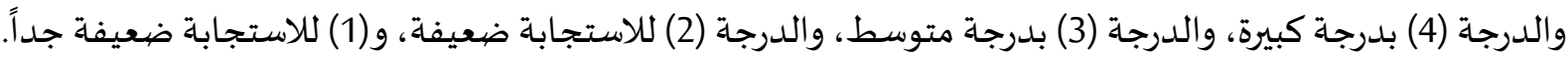
وبناء على ذلك فقد تصنيف قيم المتوسطات الحسابية لعبارات الاستبانة على النحو الاتي: جدول (3): المحك المعتمد في الدراسة

\begin{tabular}{|c|c|c|c|c|c|}
\hline من 4.21- 5 & من 3.41 - 4.20 & من 2.61 - 3.40 & من 1.81 - 2.60 & من 1- 1.80 & قيم المتوسط \\
\hline مرتفع جداً & مرتفع & متوسط & ضعيف & ضعيف جداً & المستوى \\
\hline
\end{tabular}

تم استخدام برنامج الحزم الإحصائية للعلوم الاجتماعية (SPSS) في تنفيذ الأساليب الإحصائية التالية:

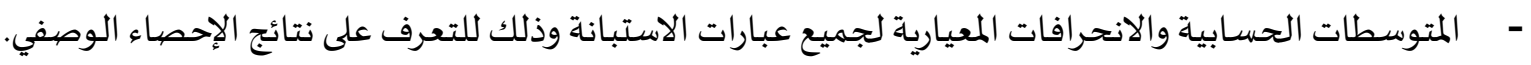

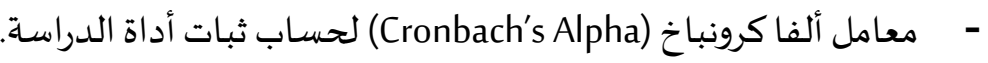

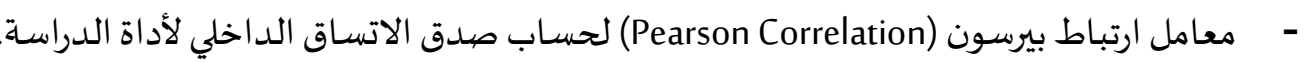
- اختبار (ت) (T-Test) لتحديد الفروق ذات الدلالة الإحصائية التي تعزى إلى متغير (النوع الاجتماعي). 
- ـ ت تحليل التباين الأحادي (ANOVA) لتحديد الفروق ذات الدلالة الإحصائية بين متوسطات استجابات أفراد عينة الدراسة والتي تعزى إلى متغير (طبيعة العمل، مكان العمل، المستوى التعليمي، الخبرة العملية).

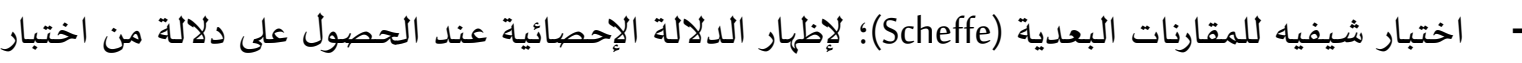
تحليل التباين الأحادي. الأداة الثانية: المقابلة: تم استخدام المقابلة شباد المهيكلة أو ما تعرف بشبه المقننة مع عينة مختارة من

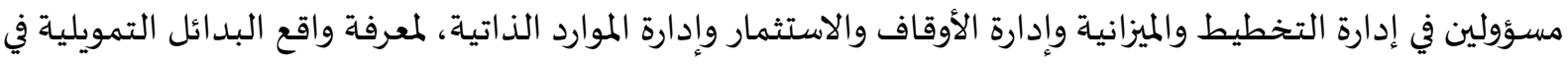
جامعة طيبة، وتوضح الخطوات التالية الطريقة التي تم استخدامها لبناء أداة المقابلة وكيفية تحليلها:

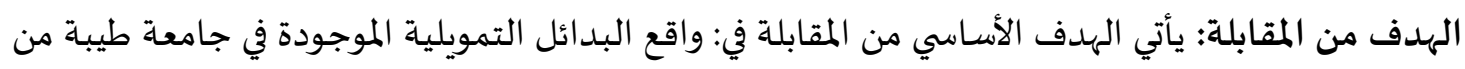

خلال النقاط التالية:

$$
\begin{aligned}
& \text { - - توضيح نسبة التمويل الحكومي لجامعة طيبة. } \\
& \text { - - تحديد نسبة التمويل الذاتي لجامعة طيبة، ومقارنتها بالتمويل الحكومي. } \\
& \text { - الكشف عن مصادر التمويل الذاتي لجامعة طيبة، والتي تولد عوائد ذاتية للجامعاة. }
\end{aligned}
$$

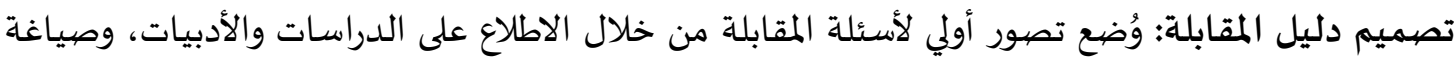

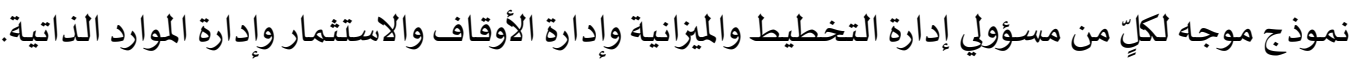
تحكيم دليل المقابلة: تم عرض دليل المقابلة على السادة المحكمين؛ لبلورة أسئلة المقابلة، واتفق المحكمون

على أسئلة المقابلة.

دليل المقابلة في صهورته النهائية: شمل دليل المقابلة مسؤولي إدارة التخطيط والميزانية وإدارة الأوقاف الاستثمار

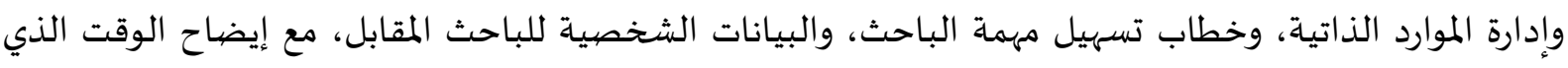

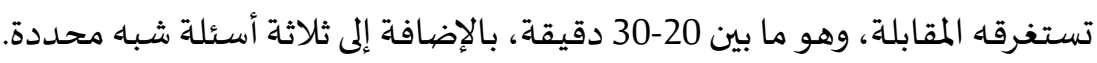

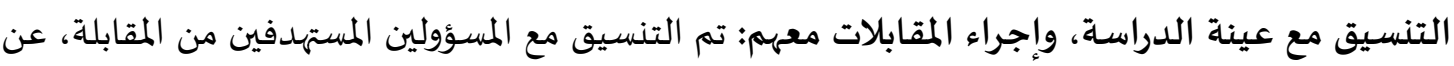

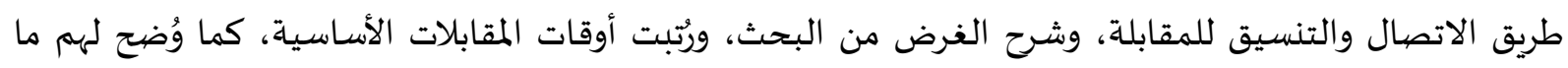

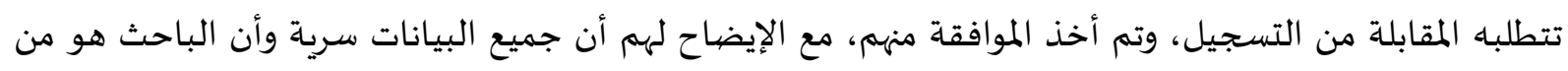

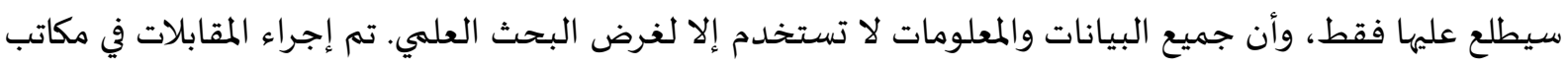

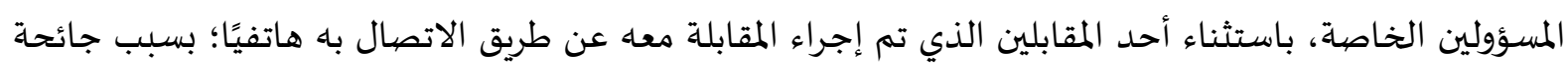

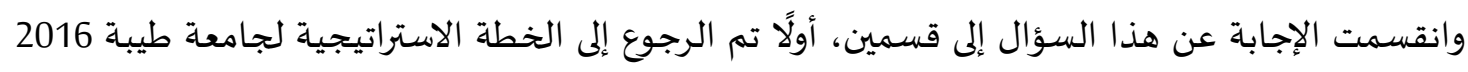

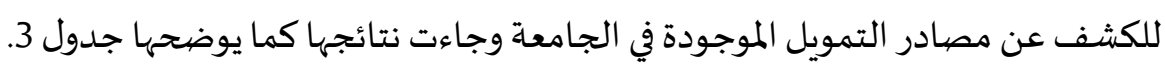


جدول (4) مصادر التمويل لجامعة طيبة

\begin{tabular}{|c|c|c|c|c|c|}
\hline \multicolumn{3}{|c|}{ مستوى الأداء المستهدف } & \multirow{3}{*}{\multicolumn{2}{|c|}{ المؤشرات }} & \multirow{3}{*}{ الاستر اتيجية } \\
\hline 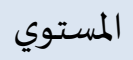 & الخطة الثانية & الخطة الآولى & & & \\
\hline الامتل & $2010-2012$ & $2011-2007$ & & & \\
\hline$\% 15$ & $\% 10$ & $\% 5$ & مشاريع البحـوث الاستشـارية والتعاقدية. في الدخل المتحقق من. & $1-5$ & \multirow{5}{*}{ تنويع مصيادر } \\
\hline$\% 10$ & $\% 5$ & - & الزيادة السنوية في ريع أوقاف الجامعة. & $2-5$ & \\
\hline 4 & 2 & 1 & عدد الكراسي البحثية & 3-5 & \\
\hline$\% 15$ & $\% 10$ & $\% 5$ & الزيادة السنوية في الدخل المحقق من & 4-5 & \\
\hline$\% 25$ & $\% 10$ & $\% 5$ & نسبة الدخل المتحقق من المصيادر الذاتية & $5-5$ & \\
\hline
\end{tabular}

الخطة الاستراتيجية لجامعة طيبة 2016

يوضح جدول 4 أنها يوجد زيادة في النسبة المئوية في الدخل المتحقق من مشاريع البحوث الاستشارية والبحثية البحاية

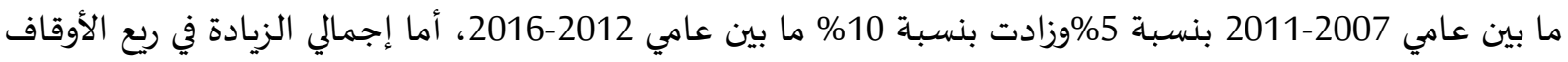

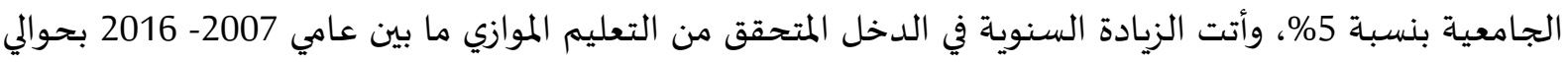

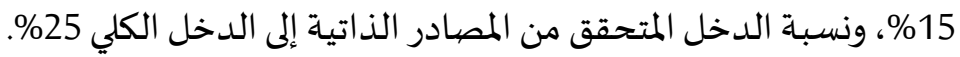

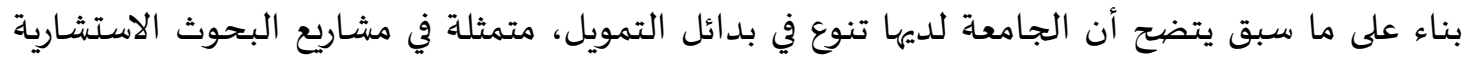

والتعاقدية، ومن أوقاف الجامعة، بالإضافة إلى الكراسي العلمية، والتعليم الموازي، أيضًا من الموارد الذاتية للجامعة.

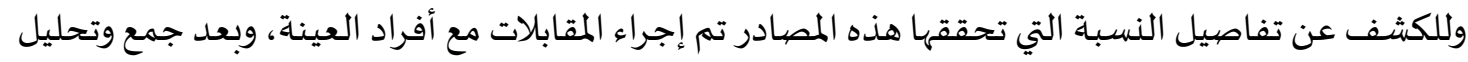

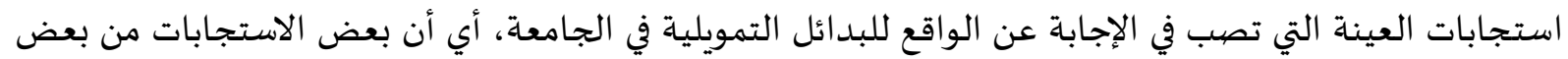
المقابلين كانت محدودة وعلى قدر السؤال، بينما أحد المستجيبين قام بالإثراء في استجاباته. ولإظهار نسبة الدعم الحكومي لتمويل جامعة طيبة صرح المسؤول (ع) أن الدعم الحكومي يمثل المصبدر الأساسي لتمويل الجامعة، فيتم صرف هذا الدعم في كل سنة مالية بعد الإقرار عليه من مجلس الوزراء، حيث يقدم على

شكل بنود، وهو المعمول به في بقية الجامعات السعودياة، وفيما يلي جدول5 بميزانية جامعة طيبة لآخر ثلاث سنوات: جدول (5) الميز انية الحكومية لجامعة طيبة خلال الثلاث السنوات الأخيرة.

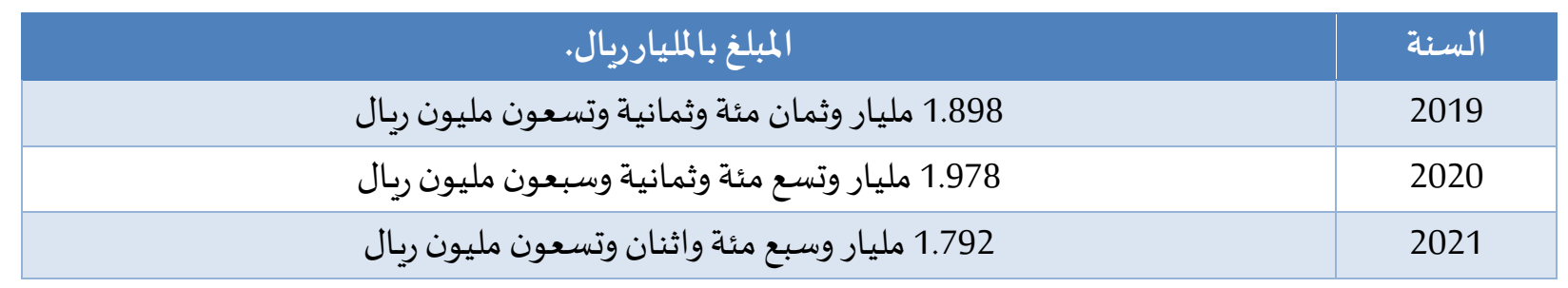

يبين جدول 5 أن ميزانية عام 2020 زادت عن ميزانية عام 2019 بمقدار 80 مليون، بينما تناقصت ميت الميزانية في مئي

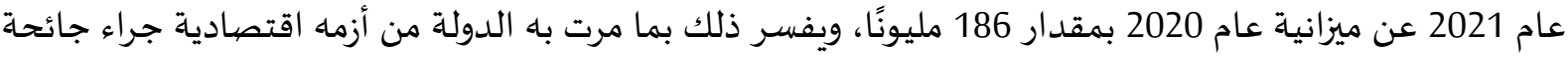
كورونا، مما اضطر الدولة إلى تقليص الميزانيات للقطاعات والمؤسسات. 
وقد صرح المسؤول (س) أن نسبة الموارد الذاتية للجامعاة تمثل تقريبًا 1\% من ميزانية الجامعة، وهذا يعد

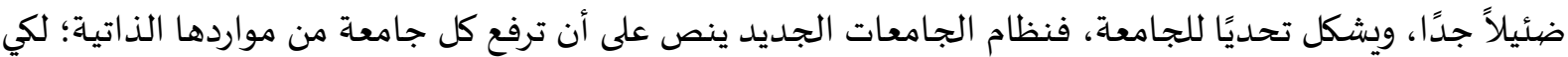
يخف الحمل عن كاهل الدولة، فلا بد للجامعة من البحث عن مصادر بديله لسد هذا العجز.

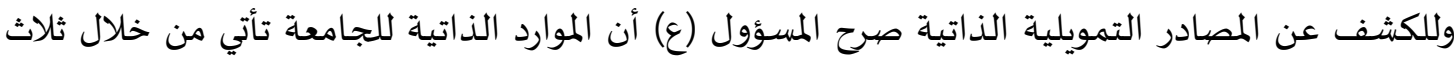
إدارات تتمثل في إدارة الموارد الذاتية، وهي المعنية بتحصيل الرسوم الدراسية للتعليم الموازي، وبرامج الماجستير والدكتوراه، وهي جهة إشرافية على مشاريع البحوث والاستشارية والتعاقدات. وإدارة الاستثمار، وهي المعنية بالتخطيط والتعاقد والاشراف على استثمارات الجامعة. وادارة الأوقاف، وهي المعنية بإدارة الوقف الجامعي وتطويره، والمسؤولة عن الشركات المتعاقدة مع الوقف مثل شركة وادي طيبة. ووضح المسؤول (م) أنه يوجد لدى الجامعة خطط استراتيجية للموارد الذاتية؛ حيث يوجد أكثر من عشرة

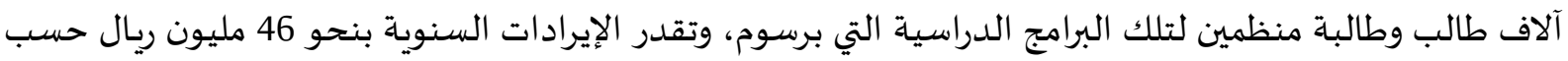

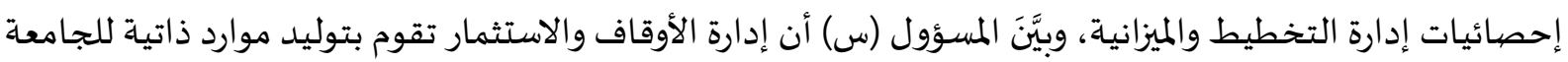

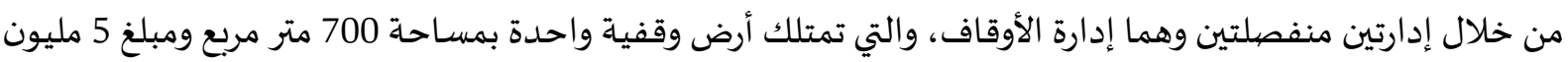

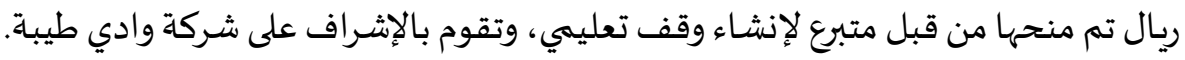

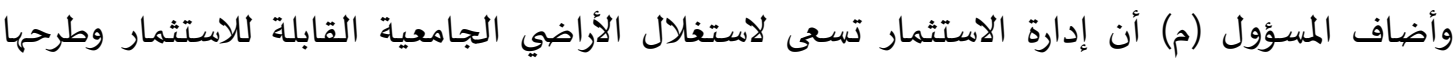

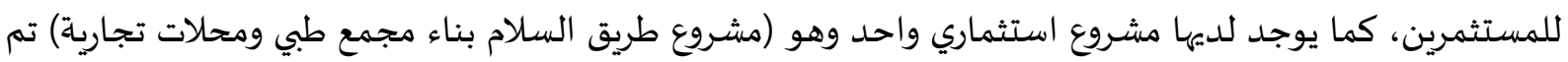

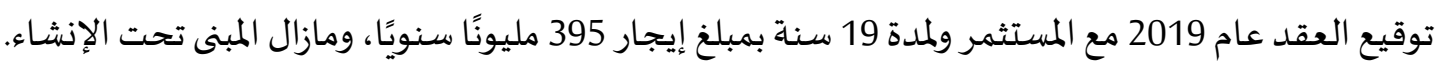

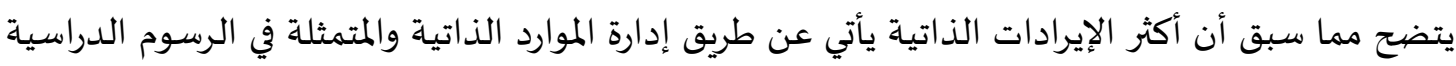

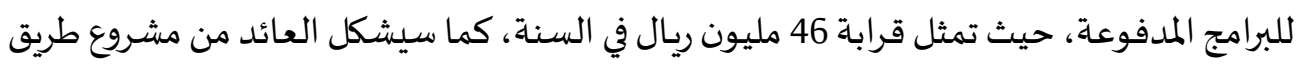
السلام، والذي يتوقع انتهاء المشروع بنهاية عام 2021 عائدًا استثماريًا جيدًا.

\section{نتائج السؤال الثاني: "ما معوقات بدائل تمويل التعليم في جامعة طيبة؟"}

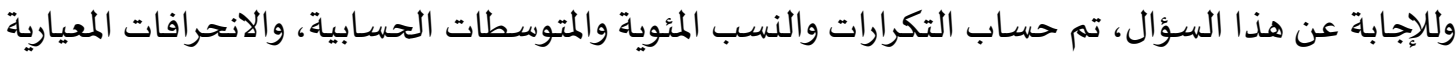
لاستجابات أفراد العينة من عمداء ووكلاء وأعضاء هيئة تدريس وموظفي ثلاث إدارات مختصابة في التمويل في الجامعة،

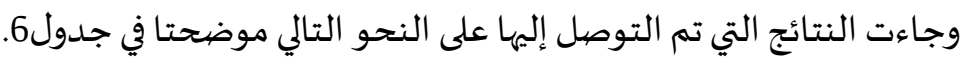

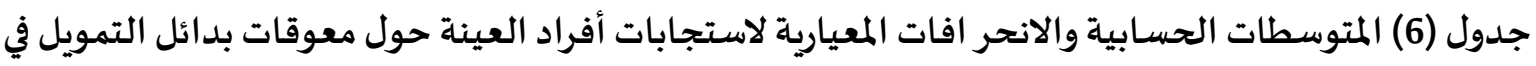

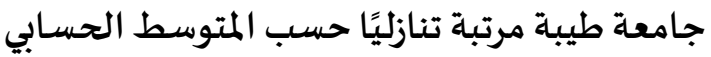

\begin{tabular}{|c|c|c|c|c|c|}
\hline 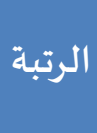 & المجوق & المعياري & المتوسط & 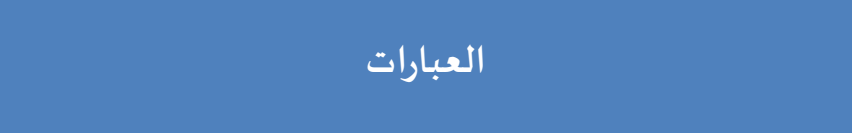 & $\hat{\imath}$ \\
\hline 1 & 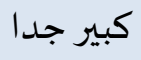 & 0.75 & .364 & 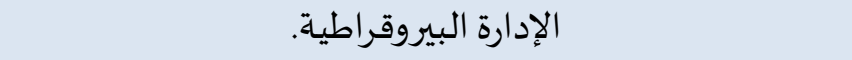 & 9 \\
\hline 2 & كبير & 0.85 & 4.18 & ضعف استثمارات القطاع الخاص في مجالات التعليم المختلفة & 7 \\
\hline 3 & كبير & 0.96 & 4.00 & محدودية الحوافز المعنوية التي تشجع أفراد المجتمع ومؤسساته & 8 \\
\hline 4 & كبير & 1.06 & 3.92 & ضعف الوقف العلمي في الجامعاة. & 2 \\
\hline
\end{tabular}




\begin{tabular}{|c|c|c|c|c|c|}
\hline الرتبة & 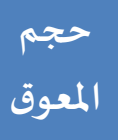 & 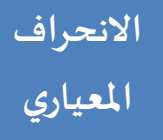 & المتوسط الحسابي & العبارات & $\hat{\imath}$ \\
\hline 5 & 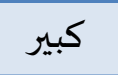 & 1.00 & 3.86 & جمود الأنظمة المالية في التعليم العالي. & 5 \\
\hline 6 & كبير & 1.00 & 3.84 & عدم وجود رؤية واضحاة للبدائل التمويلية على مستوى & 4 \\
\hline 7 & كبير & 1.10 & 3.86 & الاعتقاد لدى أفراد المجتمع أن الدولة مسؤولة عن نفقات & 6 \\
\hline 8 & 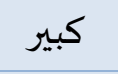 & 1.04 & 3.83 & اعتماد الجامعات على الدعم الحكومي فقط & 3 \\
\hline \multirow[t]{2}{*}{9} & كبير & 0.91 & 3.67 & ضعف مرونة الأنظمة المتعلقة بإسهام القطاع الخاص & 1 \\
\hline & كبير & 0.64 & 3.95 & المتوسط الحسابي العام & \\
\hline
\end{tabular}

يتبين من جدول 6 أن درجة تواجد معوقات بدائل التمويل لجامعة طيبة بمتوسط حسابي 3.95، مما يدل على الى المات أن أفراد العينة اتفقوا على تواجد المعوقات لبدائل التمويل الجامعي بدرجة مرتفعاة، وتتفق هذه النتيجة معات مع دراسة

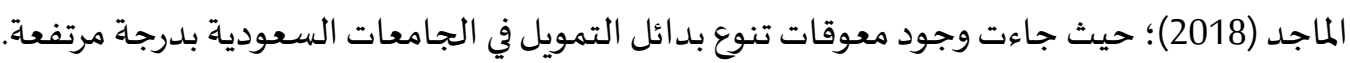

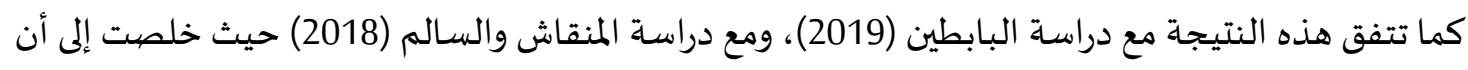
ضعف استثمارات القطاع الخاص في مجال التعليم يعد من معوقات تنوع البدائل التمويلية.

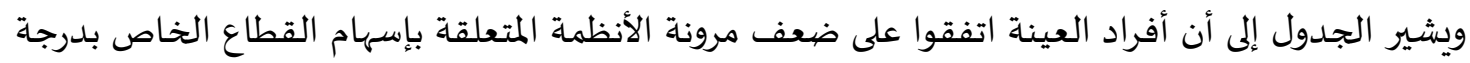

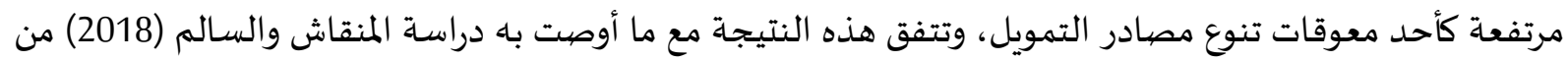

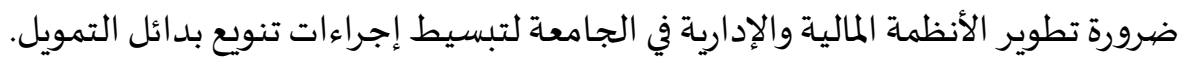

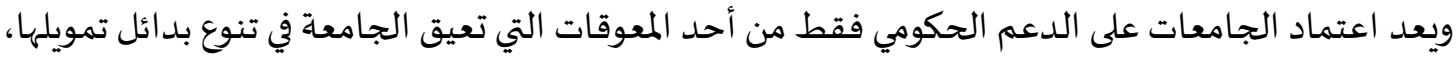

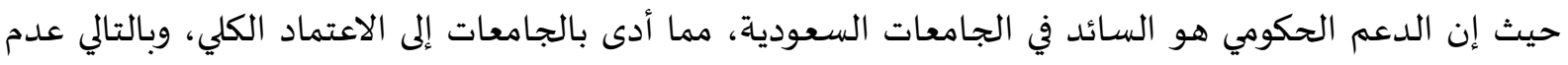

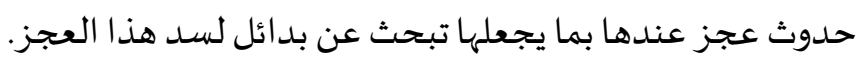
وتتفق هذه النتيجة مع دراسة الفراج (2020)، ودراسة البابطين (2019)، بالإضافة إلى ما توصل إلياه الشنيفي (2018) في أن الدعم الحكومي للتعليم العالي يعد أكبر المعوقات أمام الجامعات من تنوع مصادرهاتها.

نتائج السؤال الثالث: " ما مقترحات بدائل التمويل في جامعة طيبة في ضوء تجارب بعض الدول المتقدمة؟"

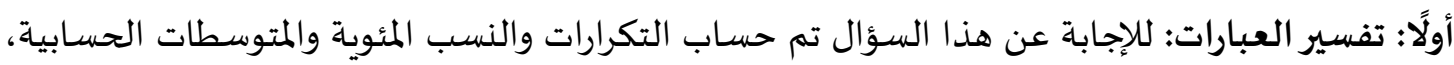

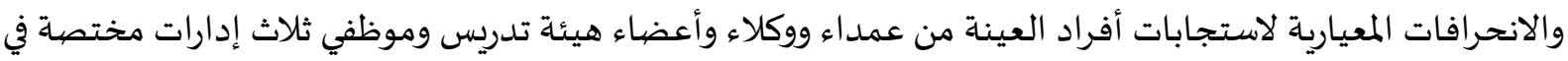

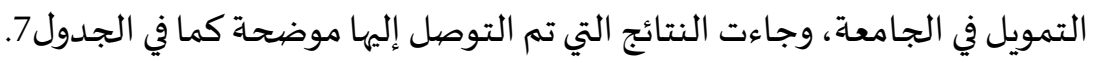

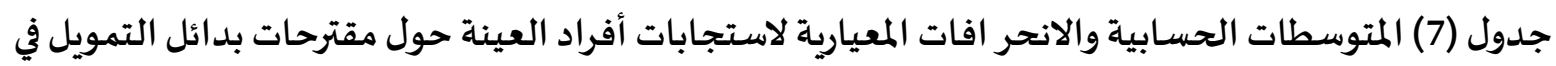

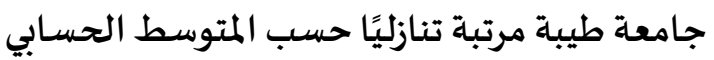

\begin{tabular}{|c|c|c|c|c|c|}
\hline الرتبة & 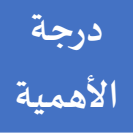 & الانمحراف & المتوسط & العبارات & $\hat{\imath}$ \\
\hline 10 & جهًا مهم & 0.77 & 4.56 & تحمل طلاب الدراسات العليا جزء من نفقات التعليم، مقابل & 17 \\
\hline
\end{tabular}




\begin{tabular}{|c|c|c|c|c|c|}
\hline 11 & & 0.67 & 4.53 & مشاركة القطاع الخاص كلفة التعليم العالي. & 12 \\
\hline 12 & & 0.72 & 4.53 & التوسع في مشاريع الأوقاف التعليمية. & 13 \\
\hline 13 & & 0.85 & 4.39 & عقد شراكات مع القطاع الخاص لتمويل البحوث والدراسات. & 15 \\
\hline 14 & & 1.01 & 4.24 & التوسع في تقديم البرامج الدراسية المدفوعة. & 19 \\
\hline 15 & & 0.96 & 4.20 & استثمار الجامعة مرافقها من المباني والتجهيزات في مشروعات & 18 \\
\hline 16 & \multirow{3}{*}{ 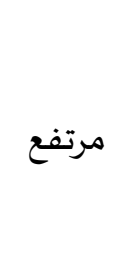 } & 1.03 & 4.19 & إتاحة المنح والقروض الطلابية في الجامعاة. & 14 \\
\hline 17 & & 1.09 & 4.06 & وضيع آلية لتشجيع رجال الأعمال ومؤسسات القطاع الخاص لتقديم & 16 \\
\hline 18 & & 1.017 & 3.96 & منح الجامعة الاستقلال الإداري (درجة مناسبة من اللامركزية). & 11 \\
\hline 19 & متوسط & 1.28 & 3.28 & الاستعانة بخبراء خارجيين للمساعدة في التخطيط لاستثمار موارد & 10 \\
\hline \multicolumn{2}{|c|}{ مرتفع جدًا } & 0.51 & 4.21 & المتوسط الحسابي العام & \\
\hline
\end{tabular}

يتبين من جدول7 أن درجة الموافقة على مقترحات بدائل التمويل لجامعة طيبة من وجهة نظر أفراد العينة

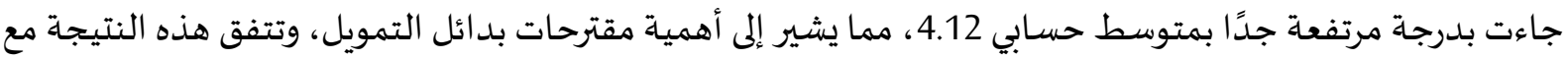
دراسة الفراج (2020) حيث جاءت المقترحات لتمويل الجامعات السعودية بلدرجة مرتفعة.

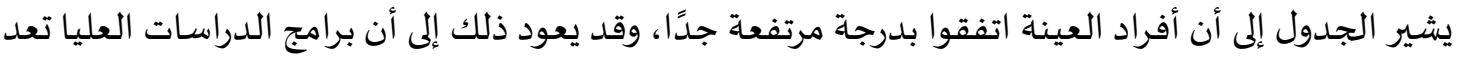
برامج تعليمية إضافياة، وتكلف الجامعة ميزانية عالية، كما أن العائد الفردي منها أكبر من العائد الاجتماعي مقارنة

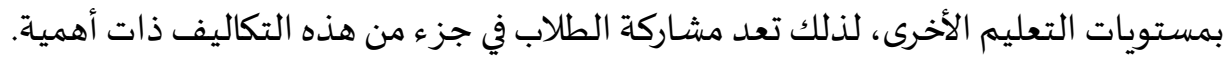

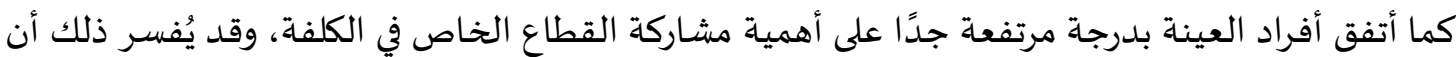
القطاع الخاص هو المستفيد الأكبر من مخرجات الجامعة من قوى بشرية مدربة، لذلك لابد من مشاركة مؤسسات

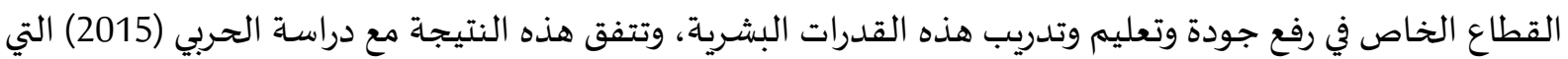

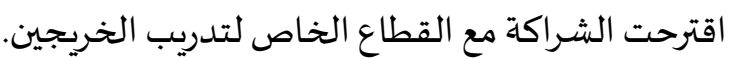
ومن المقترحات أيضًا منح الجامعة الاستقلال الإداري (درجة مناسبة من اللامركزية)" حيث جاءت بدرجة مرتفعة، وقد يعود ذلك إلى أن الاستقلالية قد تسمح للجامعاة باتخاذ قرارات بشأن تنوع بدائل التمويل، ويؤكد ذلك ما أوصت به دراسة الحربي (2015) بمنح الجامعات الصلاحيات الإدارية والمالية التي تمكها من الاستثمار.

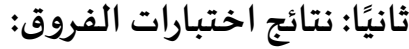

فيما يخص الكشف عن الفروق الإحصائية بين متوسطات آراء أفراد العينة بجامعة طيبة حول محاور الاستبانة (معوقات البدائل التمويلية في جامعة طيبة، ومقترحات البدائل التمويلية لجامعة طيبة في ضوء تجارب بعض

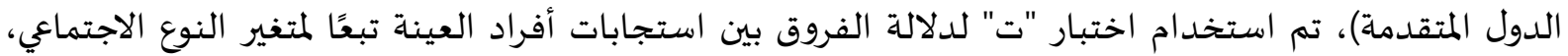

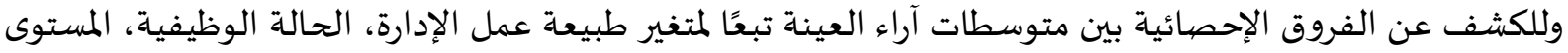
التعليمي، عدد سنوات الخبرة في المنصب الذي تشغله حاليًا، وتم استخدام تحليل التباين الأحادي (ANOVA) لإظهار الدلالة الإحصيائية عند الحصول على دلالة اختبار تحليل التباين الأحادي، وذلك على النحو الآتي: 
أولاً: متغير النوع الاجتماعي: ينقسم متغير النوع الاجتماعي إلى مستويين (ذكور وإناث)؛ لذا تم استخدام اختبار "ت" لعينتين مستقلتين، للمقارنة بين متوسطي آراء أفراد عينة الدراسة حول مجالات الاستبانة تبعًا لمتغير الجنس، التي

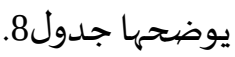

جدول (8) قيمة اختبار"ت" لدلالة الفروق بين متوسطي آراء أفراد العينة حول مجالات الاستبانة تبعًا لمتغير النوع الاجتماعي

\begin{tabular}{|c|c|c|c|c|c|}
\hline 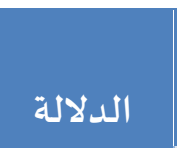 & 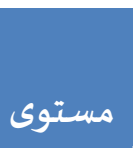 & 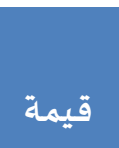 & 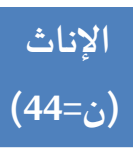 & 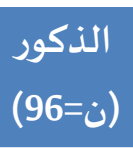 & \multirow{2}{*}{ 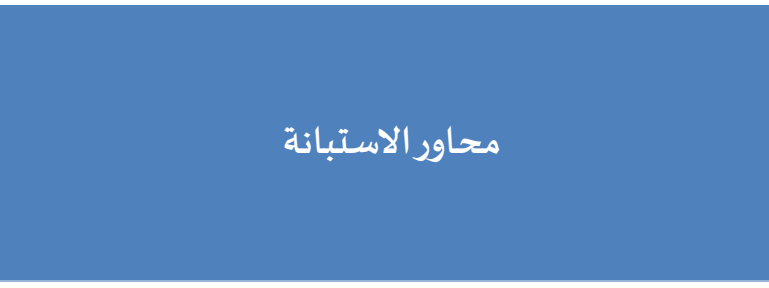 } \\
\hline الاحصيائية & 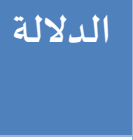 & 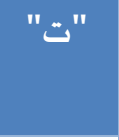 & المتوسط المسابي & المتوسط & \\
\hline 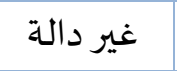 & 0.085 & 1.856 & 3.81 & 4.01 & المحور الأول: معوقات البدائل التمويلية في جامعة طيبة. \\
\hline 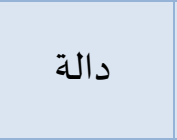 & 0.005 & 2.883 & 4.03 & 4.29 & المحور الثاني: مقترحات البدائل التمويلية لجامعة طيبة في \\
\hline 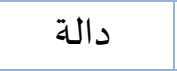 & 0.045 & 2.369 & 3.92 & 4.15 & الدرجة الكلية للاستبانة. \\
\hline
\end{tabular}

يتضح من جدول8 أنه توجد فروق ذات دلالة إحصائية عند مستوى0.05 بين أفراد عينة الدراسة بالنسبة

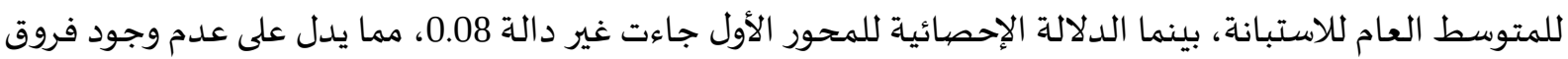

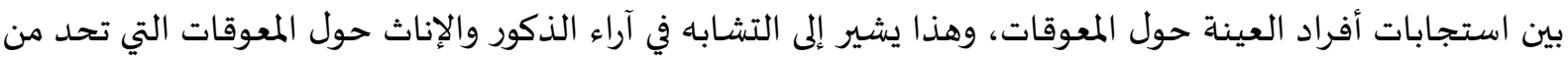
البدائل التمويلية في الجامعة.

كما يبين الجدول أن هناك دلالة إحصائية للمحور الثاني عند مستوى 0.05، مما يشير إلى وجود فروق ذات دلالة إحصائية بين استجابات الذكور والإناث حول مقترحات البدائل التمويلية للجامعة في ضوء التجارب العالمياة، وجاء

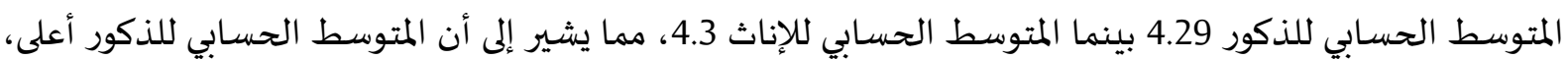
لذلك جاءت الفروق الإحصائية لصالح الذكور.

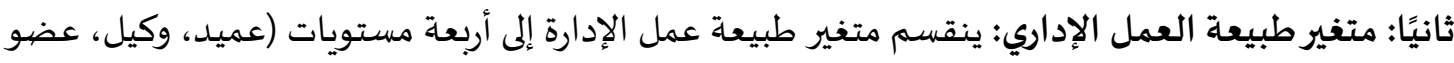
هيئة تدريس، موظف إداري)؛ وتم استخدام اختبار تحليل التباين الأحادي (ANOVA) لدلالة الفروق بين آراء عينة

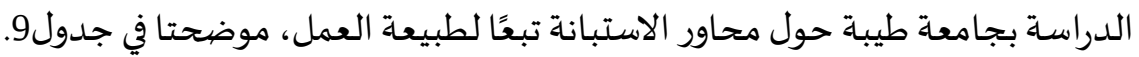

جدول (9) اختبار تحليل التباين الأحادي لدلالة الفروق بين آراء عينة الدراسـة حول محاور الاستبانة تبعًا لمتفير طبيعة العمل الإداري.

\begin{tabular}{|c|c|c|c|c|c|c|c|}
\hline الإحصائية الدلالة & مستوى الدلالة & "فيمة & موظف & عضوريس & وكيل (ن=15) & عميد(ن=5) & متحاور \\
\hline & & & المتوسط & المتوسط & المتوسط & المتوسط & \\
\hline دالة & 0.003 & 4.93 & 3.68 & 3.96 & 4.34 & 4.38 & المعوقات \\
\hline دالة & 0.029 & 3.09 & 4.21 & 4.14 & 4.55 & 4.44 & المقترحات \\
\hline دالة & 0.032 & 4.01 & 3.94 & 4.05 & 4.44 & 4.41 & المتوسط العام \\
\hline
\end{tabular}


يتضح من جدول9 أن قيمة (ف) دالة إحصائية في جميع محاور الاستبانة، وأنه توجد فروق ذات دلالة

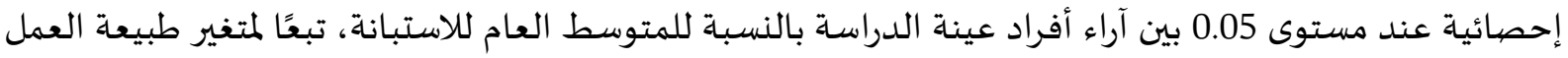

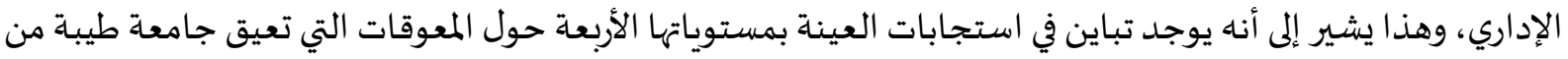

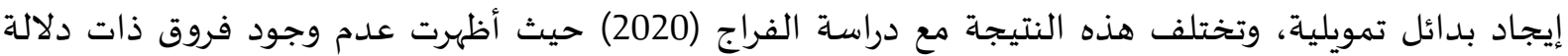
إحصائية حول معوقات تمويل الجامعات تبعًا لمتغير العمل الإداري.

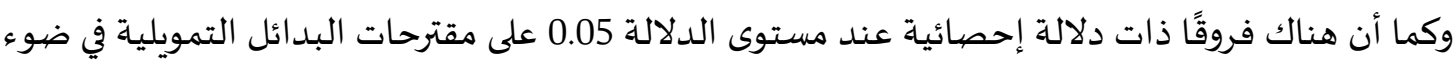

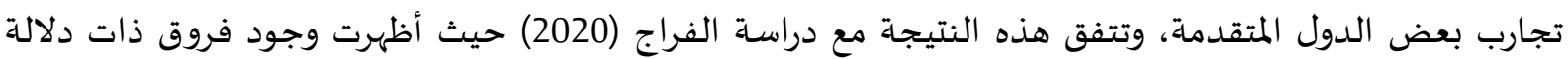
إحصائية حول مقترحات تمويل الجامعات تبعًا لمتغير العمل الإداري.

ولمعرفة اتجاه الفرق لصالح أي مستوى من مستويات طبيعة العمل تم استخدام المقات المقارنات البعدية ( Post Hoc

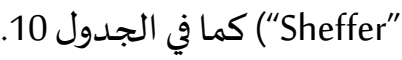
جدول (10) المقارنات البعدية للفروق الإحصائية بين استجابات أفراد العينة لمحوري معوقات البدائل ومقترحاتها تبعًا متغير طبيعة العمل الإداري

\begin{tabular}{|c|c|c|c|c|c|c|c|c|}
\hline لصالح الفرق & الدلالة & موظف & تدريس & وكيل ل & عميد & الحستوسطي & المستوى الوظليفي & متحاور الاسـتبانة \\
\hline & & & & & $\ldots$ & 4.38 & عميد & \multirow{4}{*}{ البدائل التمويلية في فعوقات } \\
\hline \multirow[t]{4}{*}{ وكيل } & 0.010 & 0.658 & & $\cdots$ & & 4.34 & وكيل & \\
\hline & & & $\cdots$ & & & 3.96 & عضو هيئة تدريس & \\
\hline & & $\cdots$ & & & & 3.68 & موظف إداري & \\
\hline & & & & & $\cdots$ & 4.44 & عميد & الثاني: مقترحات \\
\hline \multirow[t]{3}{*}{ وكيل } & 0.046 & & 0.404 & $\cdots$ & & 4.55 & وكيل & البدائل التمويلية \\
\hline & & & $\cdots$ & & & 4.14 & عضو هيئة تدريس & للجامعة في ضوء \\
\hline & & $\cdots$ & & & & 4.21 & موظف إداري & التجارب العالمية \\
\hline
\end{tabular}

يتضح من جدول10 أن الفروق بين متوسطات استجابات أفراد عينة الدراسة لجميع المحاور الاستبانة، كانت

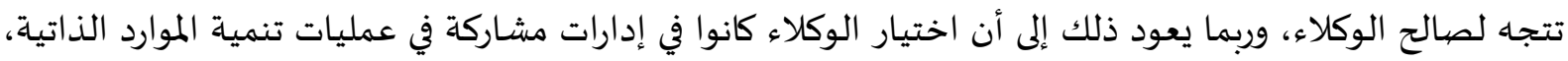

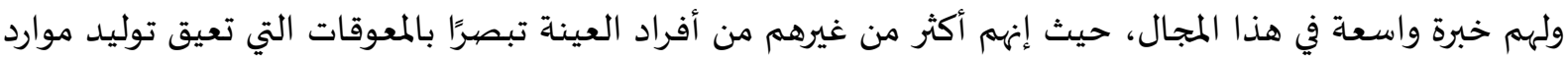

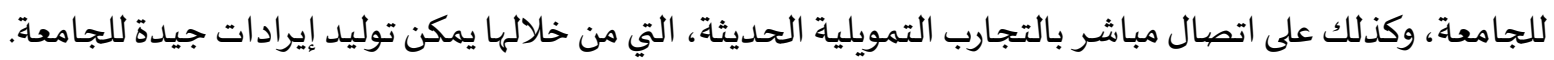

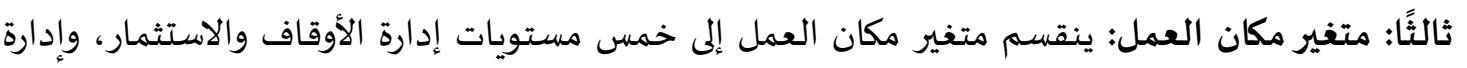
التخطيط والميزانية، وإدارة الموارد الذاتية، والكلية، وأخرى؛ وتم استخدام اختبار تحليل التباين الأحادي (ANOVA)

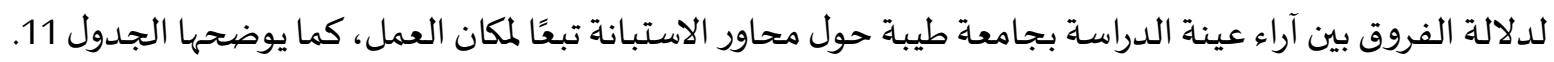

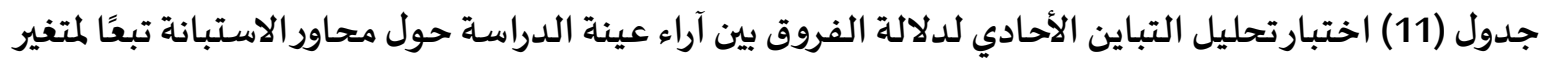
مكان العمل.

\begin{tabular}{|c|c|c|c|c|c|c|c|c|}
\hline الاحصلائة & مستوى اللالاة & "فيمة & 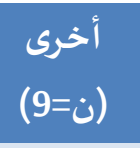 & (ن) & الذاتية (ن=ارة الموارد) & والمارة التخطية انية(ن=4) & والاستثمارة الأوقاف & متحاور \\
\hline & & & المتوسط & المتوسط & المتوسط & المتوسط & المتوسط & \\
\hline غير دالة & 0.138 & 1.772 & 3.88 & 4.01 & 3.62 & 3.42 & 3.93 & المعوقات \\
\hline
\end{tabular}




\begin{tabular}{|c|c|c|c|c|c|c|c|c|}
\hline المير دالة & 0.803 & 0.408 & 4.41 & 4.20 & 4.17 & 4.18 & 4.28 & المتوسط \\
\hline
\end{tabular}

يتضح من الجدول 11 أنه لا يوجد فروق ذات دلالة إحصائية عند مستوى 0.05، بين آراء أفرد عينة الدراسة

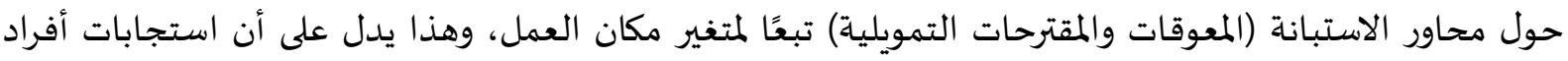

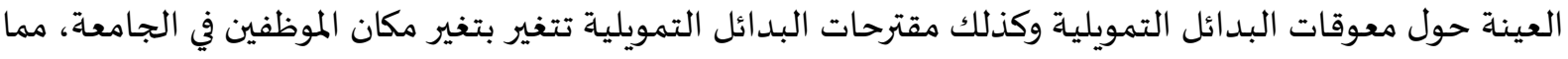

$$
\text { يدل على تشابه استجابات أفراد العينة حول عبارات الاستبانة. }
$$

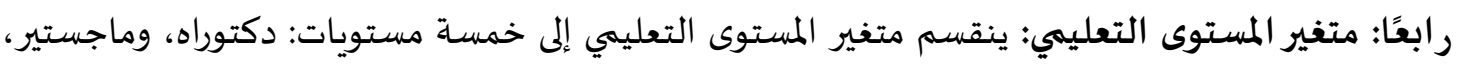

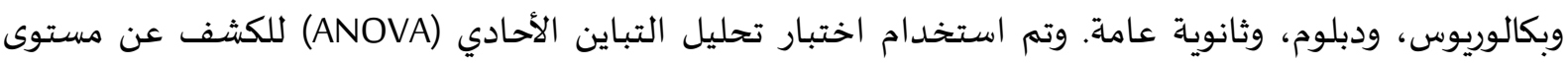

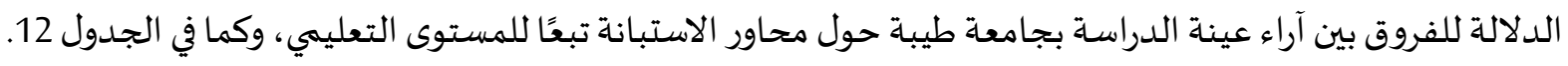

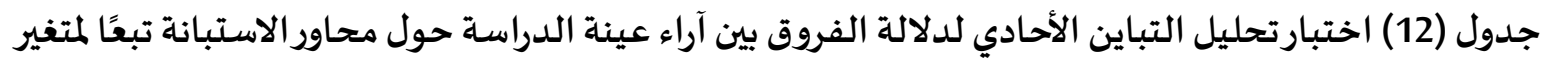

\section{المستوى التعليهي.}

\begin{tabular}{|c|c|c|c|c|c|c|c|c|}
\hline \multirow{2}{*}{ الإحصيائية } & \multirow{2}{*}{ مستوى الدلالة } & \multirow{2}{*}{ "فيمة } & ثانوية (ن=2) & (ن=وب) & بكالوريوس & ماجستير & $\begin{array}{l}\text { دكتوراه } \\
\text { (ن=94) }\end{array}$ & \multirow{2}{*}{ الاستبانة } \\
\hline & & & المتوسط & المتوسط & المتوسط & المتوسط & المتوسط & \\
\hline غير دالة & 0.87 & 2.366 & 4.00 & 3.64 & 3.82 & 3.84 & 4.04 & المعوقات \\
\hline غير دالة & 0.43 & 0.367 & 4.40 & 4.24 & 4.23 & 4.14 & 4.22 & المقترحات \\
\hline غير دالة & 0.17 & 1.366 & 4.20 & 3.94 & 4.03 & 3.99 & 4.13 & المتوسط العام \\
\hline
\end{tabular}

يتضح من جدول 12 أنه لا توجد فروق ذات دلالة إحصائية عند مستوى 0.05، بين آراء أفرد عينة الدراسة

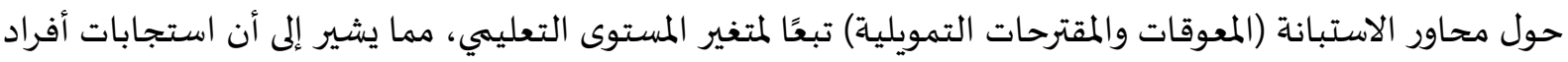

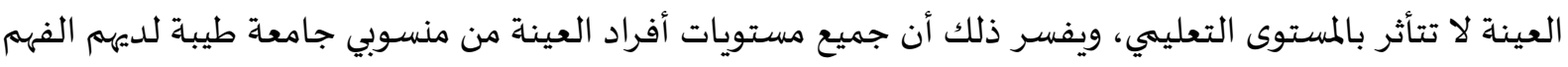
الواضح حول معوقات ومقترحات بدائل التمويل.

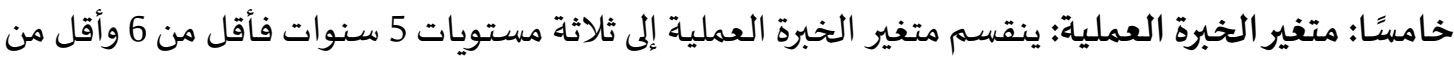

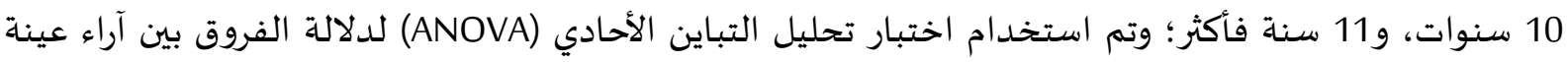

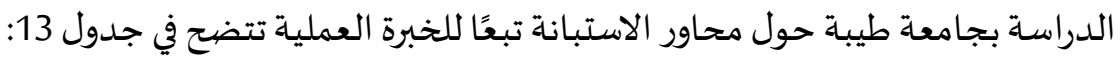

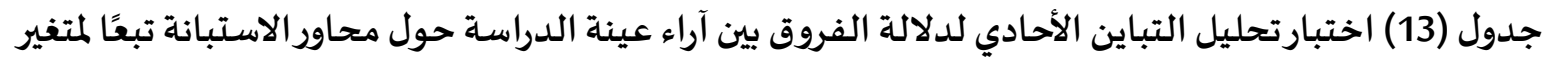

\section{الخبرة العملية}

\begin{tabular}{|c|c|c|c|c|c|c|}
\hline \multirow[t]{2}{*}{ الدلالة } & مستوى & "فيمة قفة & 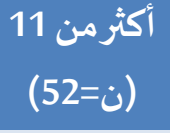 & سنوات 6 و أقل من 10 من 10 & 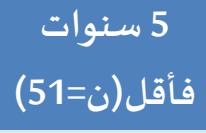 & \multirow[t]{2}{*}{ محاور الاستبانة } \\
\hline & & & المتوسط & المتوسط & المتوسط & \\
\hline غير دالة & 0.014 & 4.436 & 3.97 & 3.70 & 4.10 & المعوقات \\
\hline غير دالة & 0.212 & 1.568 & 4.20 & 0.720 & 4.30 & المقترحات \\
\hline غير دالة & 0.113 & 3.002 & 4.08 & 3.90 & 4.20 & المتوسط العام \\
\hline
\end{tabular}


يتضح من جدول 13 السابق أنه لا توجد فروق ذات دلالة إحصائية عند مستوى 0.05، بين آراء أفرد عينة

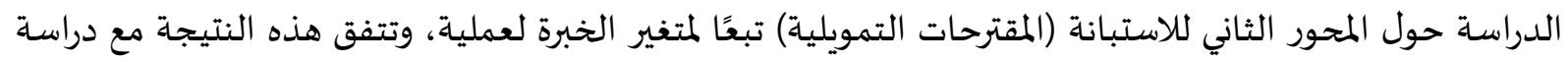
الفراج (2020)؛ حيث أظهرت عدم وجود فروق ذات دلالة إحصائية حول مقترحات تمويل الجامعات تبعًا لمتغير العمل

بينما توجد فروق ذات دلالة إحصائية عند مستوى دلالة 0.05 بين استجابات أفراد العينة حول محور

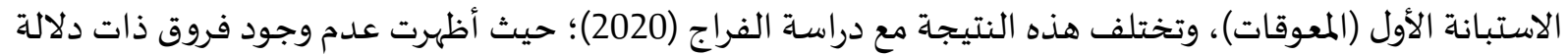

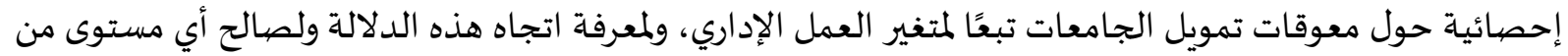

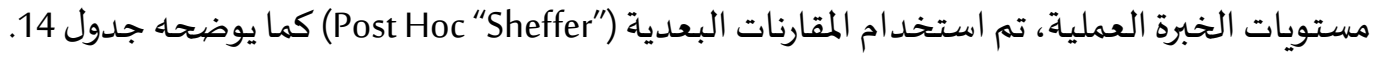

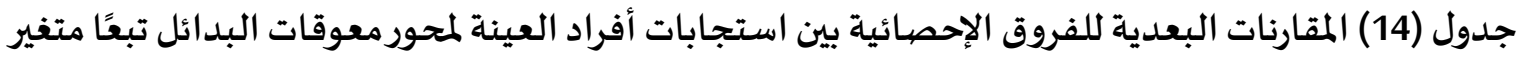
الخبرة العلمية

\begin{tabular}{|c|c|c|c|c|c|c|c|}
\hline الفرق لصيالح & الدلالة & أكثرمن & سن سنوات & 5 سأقلوات & المتوسطابي & مستوى الخبرة & المحور \\
\hline \multirow[t]{3}{*}{5 سـنوات فأقل } & 0.014 & & 0.401 & $\ldots \ldots$ & 4.10 & 5 سنوات فأقل & المحور \\
\hline & & & $\ldots \ldots$ & & 3.70 & من 6-10سنوات & الأول: \\
\hline & & $\ldots \ldots$ & & & 3.97 & 11 سنة فأكثر & المعوقات \\
\hline
\end{tabular}

يتضح من جدول 14 أن الفروق بين متوسطات استجابات أفراد العينة تتجه لصالح الأفراد الذين خبرتهم 5

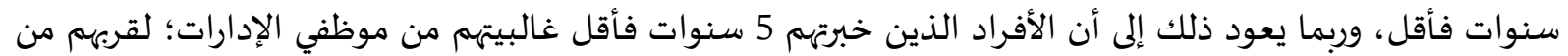

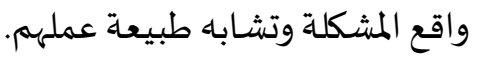

\section{ملخص النتائج التي توصلت إلهها الدراسة كالتالي}

يوجد لدى جامعة طيبة بدائل تمويلية متمثلة في مشاريع البحوث الاستشارية والتعاقدية، وأوقاف الجامعاة، وأيضا

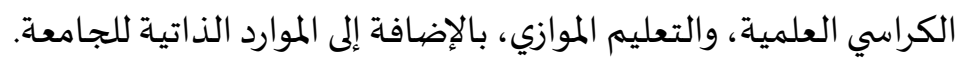

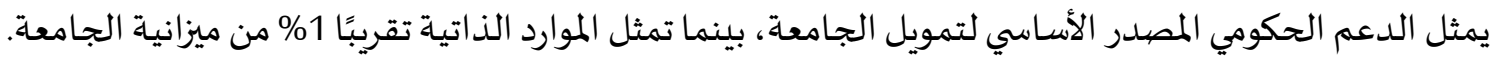

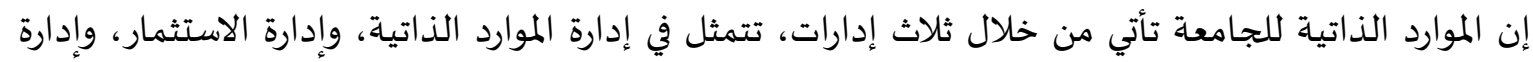
الوقف. تقدر الإيرادات الذاتية من التعليم الموازي تقريبًا 46 مليون سنويًا، من 10 آلاف طالب وطالبة.

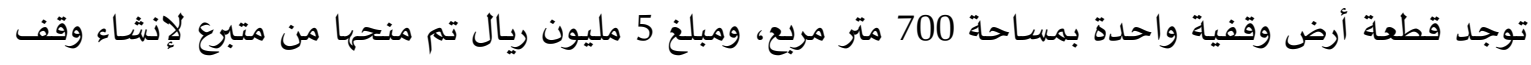
تعليمي. حققت معوقات البدائل التمويلية على المستوى الكلي درجة تواجد مرتفعة بمتوسط حسابي 3.95.

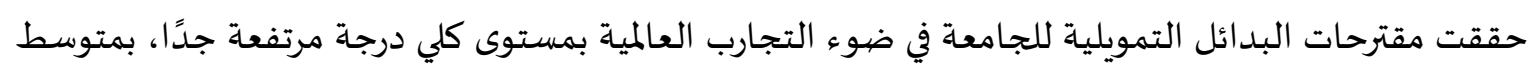
حسابي 4.21. لا توجد فروق ذات دلالة إحصائية عند مستوى 0.05 بين متوسطات استجابات أفراد العينة على معوقات البدائل

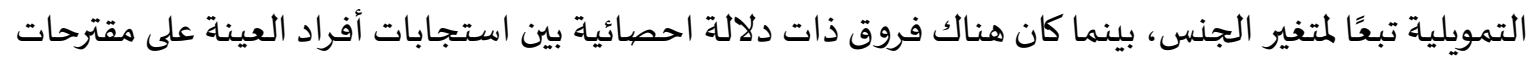

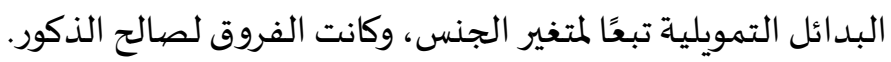


توجد فروق دالة إحصائيًا عند مستوى 0.05 بين متوسطات استجابات أفراد العينة على معوقات البدائل التمويلية

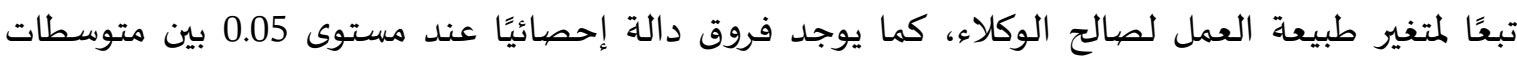

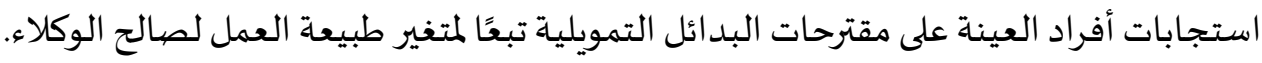

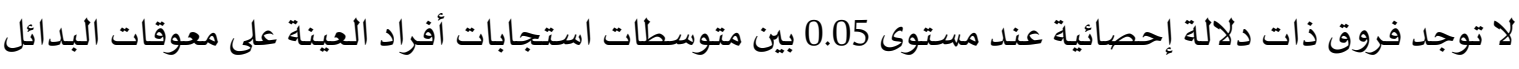

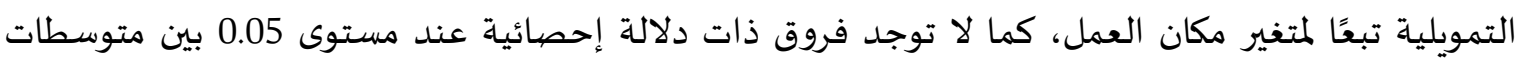

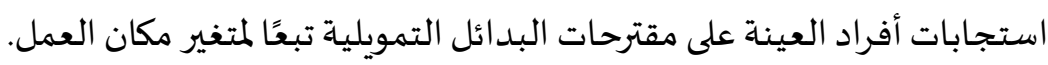

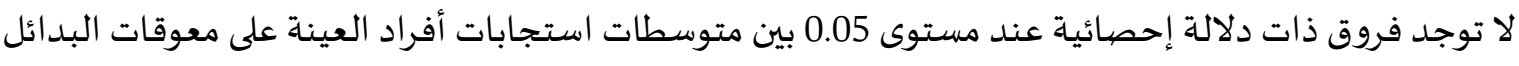

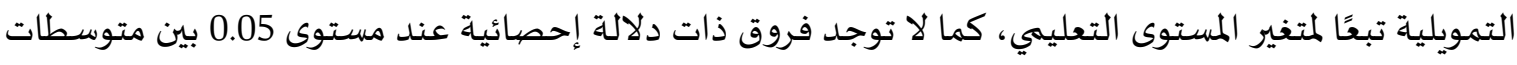

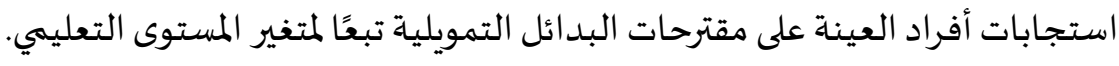

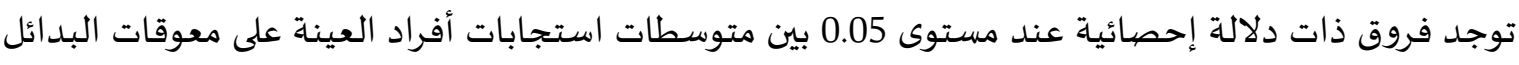

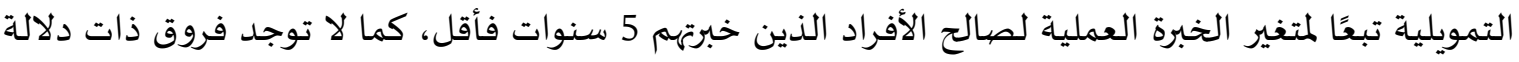

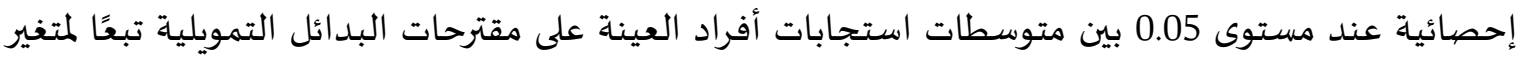

الخبرة العملية.

التوصيات والمقترحات

1. أن تعمل الجامعة على استغلال الأرض الوقفية واستثمارها، والتوسع في الاوقاف التعليمية.

2. العمل على عقد شراكات مع القطاع الخاص في دعم الدراسات والمشاريع البحثية.

3. العمل على حث القطاع الخاص مشاركة كلفة التعليم في الجامعة.

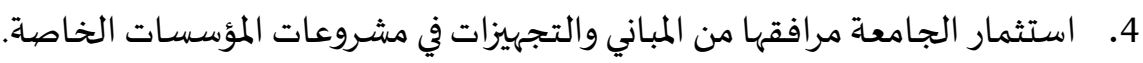

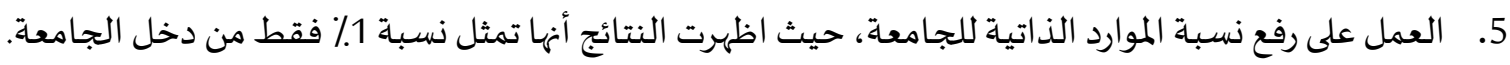
6. ت تبني فلسفة الجامعة المنتجة أسوة بالجامعات العالمياة.

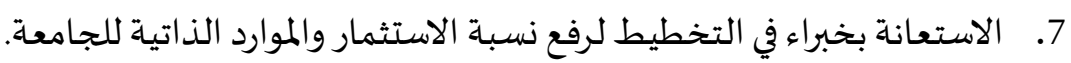

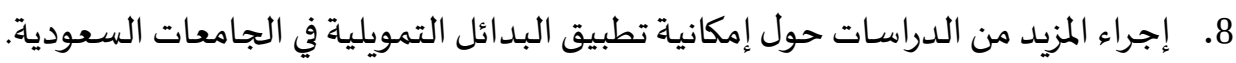

9. إجراء المزيد من الدراسات حول معوقات البدائل التمويلية في الجامعات السعودية.

قائمة المراجع

أولاً - المراجع بالعربية

- البابطين، أماني. (2019). تنوع مصادر نظام تمويل التعليم في المملكة العربية السعودية لمواكبة تطلعات رؤية 2030

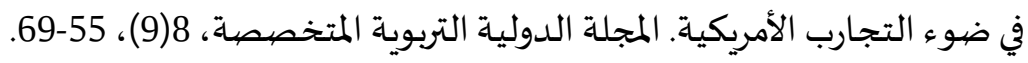

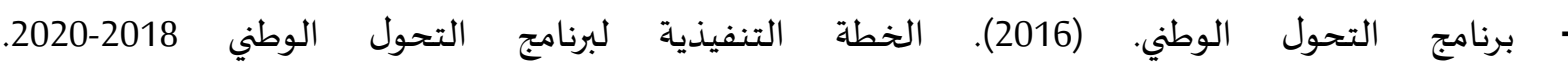
https://www.vision2030.gov.sa/sites/default/files/attachments/NTP\%20Arabic\%20Public\%20Docu ment\%202810_0.pdf 
جامعة طيبة. (1438). الخطة الاستراتيجية العامة لجامعة طيبة 1483- 1445(الملخص التنفيذي). جامعة طيبة. https://www.taibahu.edu.sa/Pages/AR/DownloadCenter.aspx?Siteld=96d5422e-8e52-4a2c-adf7bf7e8791cb20\&Fileld=53ef8356-6329-40cf-9462-ecc555d98f88 الجميعي، وفاء. (2015). الاتجاهات العالمية المعاصرة في تمويل التعليم العالي: النموذج البريطاني، عالم التربية، .78-56، (52)16

الحربي، أمل. (2017). تمويل التعليم في المملكة العربية السعودية تحديات وبدائل. مجلة العلوم التربوية، 1(2)، .87-58

الحربي، محمد. (2015). بدائل مقترحة لتمويل التعليم في الجامعات الحكومية بالمملكة العربية السعودية. مجلة كلية التربية، 26(103)، 141-172-172. حسين، خالد. (2011). التمويل الذاتي مدخلاً لدعم التعليم الجامعي الحكومي في مصر، مجلة البحث العلمي في التربية، 12(3)، 705-726.

الدمخ، أمينة؛ البارقي، مصلحة؛ العتيبي، سامية. (2019). تصيور مقترح لتطوير نظام تمويل التعليم بالمملكة

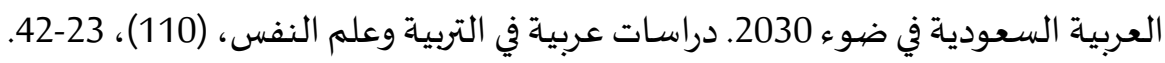

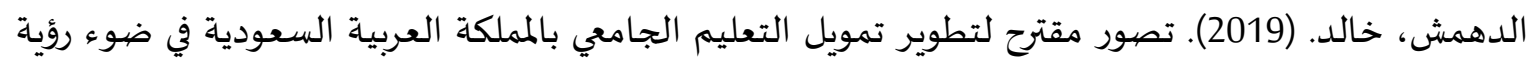

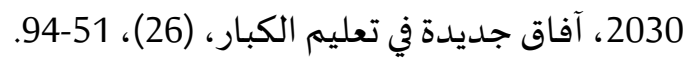

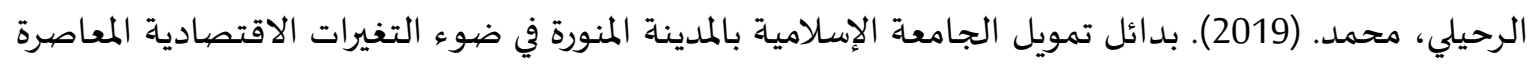

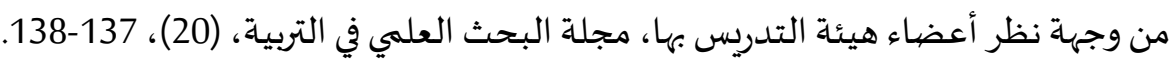

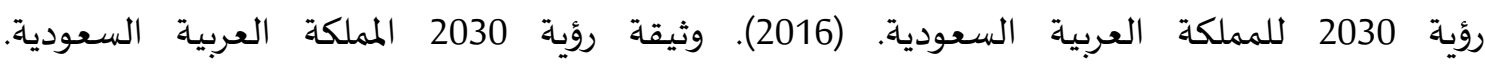
2https://vision2030.gov.sa/download/file/fid/42 شاهين، محمد. (2018). الاقتصاد المعرفي وأثرة على التنمية الاقتصادية للدول العربية. دار حميثرا للنشر والترجمة. الشمري، عيادة. (2016). علاقة جامعة حائل بالمجتمع في ضوء معايير الهيئة الوطنية للتقويم والاعتماد الأكاديمي.

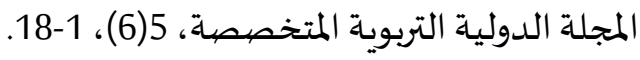

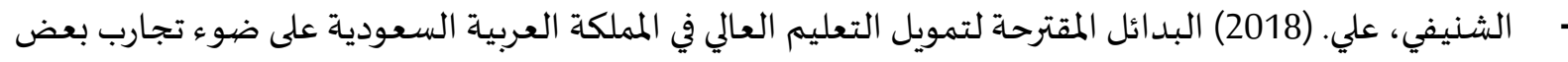

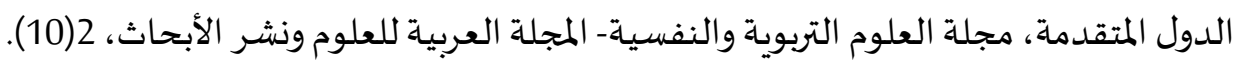

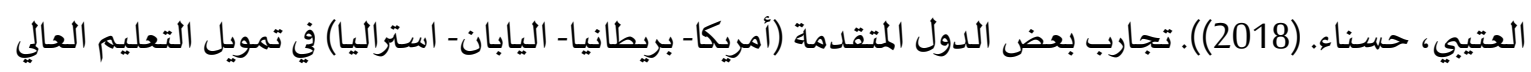

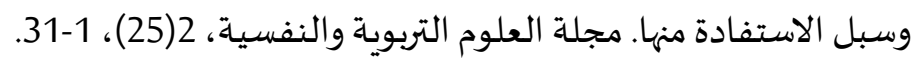
عسيري، زهرة. (2017). تسويق البحوث العلمية في الجامعات السعودية من منظور اقتصاد المعرفة دراسة تطبيقية بجامعة الملك خالد [رسالة ماجستير غير منشورة]، جامعة الملك خالد. العقيل، سيناء؛ العيسى، إيناس. (2019) حوكمة تنويع مصادر التعليم وتحين الكفاءة المالية لقطاع التعليم

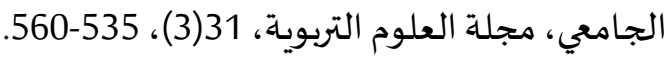
عيسان، صالحة. (2016). آليات مقترحة لتنويع مصادر تمويل التعليم العالي في سلطنة عممان بالإفادة من خبرة

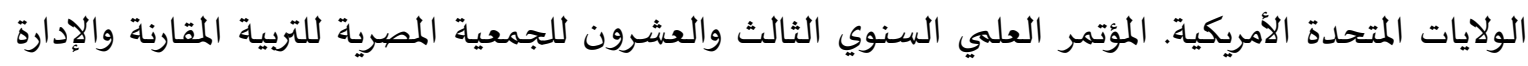

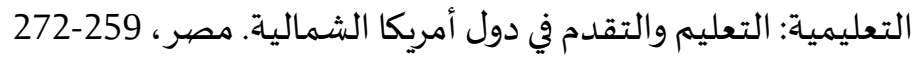


الفراج، لولوة. (2020). تمويل التعليم العالي في المملكة والعربية السعودية، التحديات والحلول. مجلة العلوم التربوية والإنسانية، (1)، 30-40. لونوه

اللجنة العليا لسياسة التعليم (1995). وثيقة سياسة التعليم في المملكة. وزارة التربية والتعليم، المملكة العربية السعودية، المادة (232)، ص24.

الماجد، ابتسام. (2018). صور مقترح لبدائل تمويلية في الجامعات السعودية في ضوء فلسفة الجامعة. مجلة الجامعة الإسلامية لدراسات التربوية، 6، 30-52.

المالكي، عبد الله. (2013). بدائل تمويل التعليم العالي الحكومي في المملكة العبربية السعودية، المجلة المبلة السعودية للتعليم العالي، (10)، 113-147. المنقاش، سارة؛ السالم، غادة. (2018). تنويع مصادر التمويل في جامعة الملك سعود في ضوء تجربة جامعة أكسفورد. مجلة الفنون والأدب وعلوم الإنسانيات والاجتماع، (22)، المادة، https://pf.moe.gov.sa/ar/Pages/home.aspx الموقع الإعلامي لوزارة التعليم. (2020)

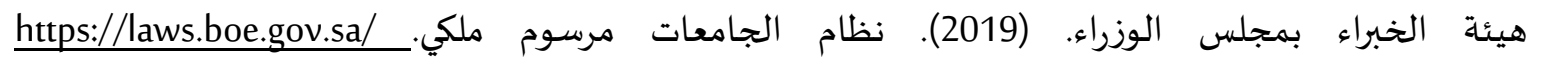
BoeLaws/Laws/LawDetails/8ee74282-7f0d-49ff-b6ee-aafc00a3d801/1 وزارة الاقتصاد والتخطيط، (2015). موجز خطة التنمية العاشرة وأولوياتها. وزارة التخطيط https://extranet.who.int/countryplanningcycles/sites/default/files/planning_cycle_ والاقتصاد. repository/saudi_arabia/10th-development-plan-.pdf وزارة التعليم العالي. (1432). الخطة المستقبلية للتعليم الجامعي في المملكة العربية السعودية الخطة التنفيذية https://taibahu.edu.sa/Pages/AR/DownloadCenter.aspx?Siteld=236d881b-bea9-4bb7-abd0-.آلآفاق $\underline{6781 a 8 b 86 f 63 \& F i l e l d=d a 135 b 1 a-f 6 a b-4 c 0 b-b 97 a-a 2865 a 20 e 187}$ https:/www.moe.gov.sa/ar/education وزارة التعليم. (2020). التعليم الجامعي- الجامعات الحكومية. /highereducation/Pages/UniversitiesList.aspx وزارة المالية. (2020). التقرير الربعي لأداء الميزانية العامة للدولة الربع الأول من السنة المالية 2020. وزارة المالية. https://www.mof.gov.sa/financialreport/budget2020/2020/Q1_A_2020.pdf وزارة المالية. (2020). المركز الإعلامي- اتخاذ عدداً من الإجراءات الإضافية لمواجهة الآثار المالية والاقتصادية الناتجة https://www.mof.gov.sa/mediacenter عن جائحة فيروس كورونا المستجد. وزارة المالية. /news/Pages/News_11052020.aspx اليونسكو. (2018). تقرير دراسات اليونيسكو لتمويل التعليم العالي في الدول العربية، مكتب اليونيسكو الإقليمي

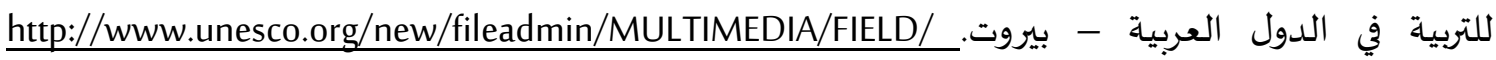
Beirut/video/Report2.pdf

ثانياً- المراجع بالإنجليزية:

- Alshamy, A. S. (2012). Funding mechanisms and quality assurance systems in Higher Education in Egypt in comparative perspective [Unpublished doctoral dissertation]. University of Birmingham. 
- Holbeck, M. (2017). Funding of higher education: Variations in state funding, impacts of state funding on differential tuition, and variables impacting differential tuition [Unpublished doctoral dissertation]. South Dakota State University.

- Neary, C. (2019). U.S. higher education performance-based funding policy diffusion and its association with state political ideologies and state budgeting taxonomies [Unpublished doctoral dissertation]. lowa State University.

- Opoczynski, R. (2016). The creation of performance funding in Michigan: Partnership, promotion and points. Education policy analysis archives, (24), 122-145

- Stalowski, N. (2021). Philanthropic funding and state appropriations at public higher education institutions [Unpublished doctoral dissertation]. The George Washington University. 